Tim S. Schubert

Florida Department of Agriculture and Consumer Services, Gainesville

Shabbir A. Rizvi

Florida Department of Agriculture and Consumer Services, Miami

Xiaoan Sun

Florida Department of Agriculture and Consumer Services, Gainesville
Tim R. Gottwald

USDA-ARS Horticultural Research Lab, Ft. Pierce, FL

James H. Graham

University of Florida, Citrus Research and Education Center, Lake Alfred

Wayne N. Dixon

Florida Department of Agriculture and Consumer Services, Gainesville

\title{
Meeting the Challenge of Eradicating Citrus Canker in Florida-Again
}

The Florida Department of Agriculture and Consumer Services - Division of Plant Industry (FDACS-DPI) and the United States Department of Agriculture - Animal and Plant Health Inspection Service (USDA-APHIS) are currently engaged in what may be the largest single regulatory agriculture program to eradicate a plant disease ever undertaken in the history of the United States, if not the world. The target is the bacterial disease of citrus known as Asian strain citrus canker, or more generally, citrus canker (CC). The eradication effort, known as the Citrus Canker Eradication Program (CCEP), is an attempt to mitigate the serious consequences this disease would have on the $\$ 8.5$ billion Florida commercial citrus industry, the privately grown residential citrus in Florida, and also to protect other citrus-producing areas of the United States that might be harmed by this disease, in particular Texas and perhaps wetter areas of California. Although seven southern and central Florida counties have recently been impacted by the disease, the worst of the $\mathrm{CC}$ infestation in Florida is unquestionably in the residential areas in Miami-Dade, Broward, and recently Palm Beach counties on the southeastern Atlantic coast. Obstacles to implementing regulatory action in this area are threatening the entire state's citrus crop and are posing historically unprecedented challenges to the plant regulatory agencies. This discussion will: (i) describe the disease and why eradication is considered the best approach for Florida citrus; (ii) outline what has changed about the disease and our overall

Dr. Schubert's address is: Florida Department of Agriculture and Consumer Services, Division of Plant Industry, P.O. Box 147100, Gainesville 32614-7100; E-mail: schubet@doacs.state.fl.us

Publication no. D-2001-0215-01F

(C) 2001 The American Phytopathological Society understanding of it in relation to present society; and (iii) enumerate the main problems encountered in the eradication program and solutions presented to date.

\section{Introduction \\ to Citrus Canker Disease}

$\mathrm{CC}$ is caused by the bacterial pathogen Xanthomonas axonopodis pv. citri (syn. Xanthomonas campestris pv. citri). It is a serious disease of most commercial citrus cultivars and some citrus relatives (62). The pathogen causes distinctive necrotic raised lesions on leaves, stems, and fruit (Fig. 1). Severe infections can cause defoliation, blemished fruit, premature fruit drop, twig dieback, and general tree decline. CC is not systemic; it causes local lesions only. Considerable regulatory effort is directed at preventing the introduction and spread of CC because it is not present in all citrus-growing regions of the world where the moist, subtropical to tropical climate is conducive to $\mathrm{CC}$ development. Although in the case of Florida, the pathogen is quite plainly an exotic invader, in fact both the pathogen and the host are introduced organisms. Citrus was introduced into the Western Hemisphere with the founding of the first colony at St. Augustine, FL, around 1565, and has since become naturalized throughout the warmer climates of the hemisphere. The pathogen that causes CC did not arrive until almost 350 years later (see History section). There are no effective disease suppression strategies against $\mathrm{CC}$ for the more susceptible cultivars of citrus grown in wet, tropical and subtropical areas. Furthermore, the unmarketability of blemished fruit for fresh consumption and the widespread regulatory prohibitions against shipping even symptomless fresh fruit from areas where CC is endemic to other citrus production areas make the economic impact much greater than that from yield and quality reductions alone.
The problem of variability within the pathogen population is inherent in $\mathrm{CC}$ as it is in many other Xanthomonas-induced diseases, and the pathogen taxonomy is not settled $(57,83)$. Several strains of CC are or have at one time been recognized around the world. Asian or A-strain canker is the most common and most damaging of the CC strains. In common parlance, this is the strain most authorities refer to as simply $\mathrm{CC}$, and that is how the term is used in this paper. The distribution of CC worldwide is depicted in Figure 2. Recently, Vernière et al. (84) designated some isolates of the Asian strain with a host range restricted naturally to key/Mexican lime (C. aurantiifolia (Christm.) Swingle) as A* strains.

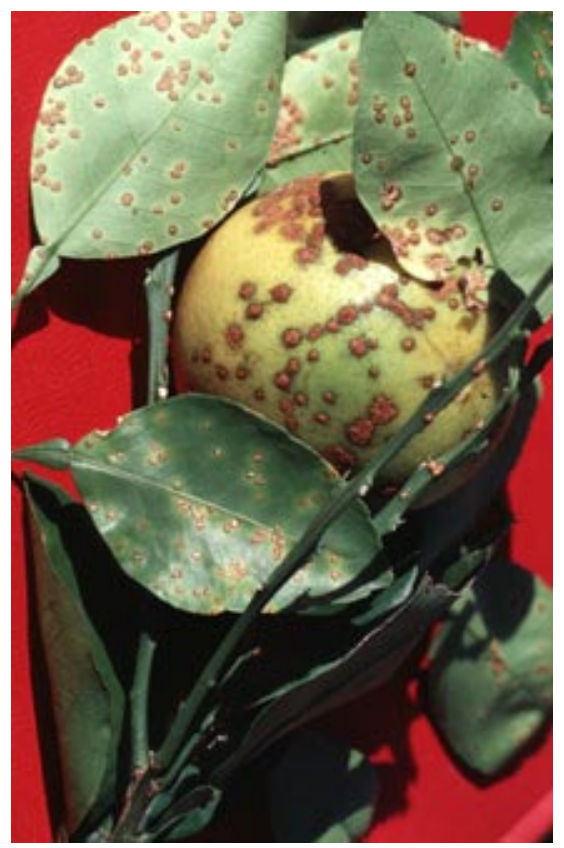

Fig. 1. Bacterial citrus canker (BCC) causes lesions on all aboveground parts of citrus when they are in the expansion phase of growth. These lesions are on grapefruit leaves, twigs, and fruit. 
B-strain, false canker, or cancrosis B first appeared in Argentina in 1923, then spread through several provinces of Argentina. Eventually, B-strain spread into neighboring Uruguay and Paraguay. Although most serious on lemon (Citrus limon (L.) Burm. f.), B-strain also infected sour orange $(C$. aurantium L.), lime $(C$. aurantiifolia (Christm.) Swingle), and rarely sweet orange $(C$. sinensis (L.) Osbeck) and pummelo (C. maxima (Burm.) Merr.) if near infected lemons. It did not infect grapefruit $(C . \times$ paradisi Macfad.) (6). B-strain is no longer found in nature, having been gradually supplanted by the Asian strain, which appeared in South America in 1972.

Mexican lime cancrosis, or C-strain, was discovered in 1963 and is present only in Brazil, infecting only key/Mexican lime (6). The B and C strains are currently classified as Xanthomonas axonopodis pv. aurantifolii.

Two other xanthomonad bacterial pathogens of citrus were once provisionally

\section{World Distribution of Citrus Canker}

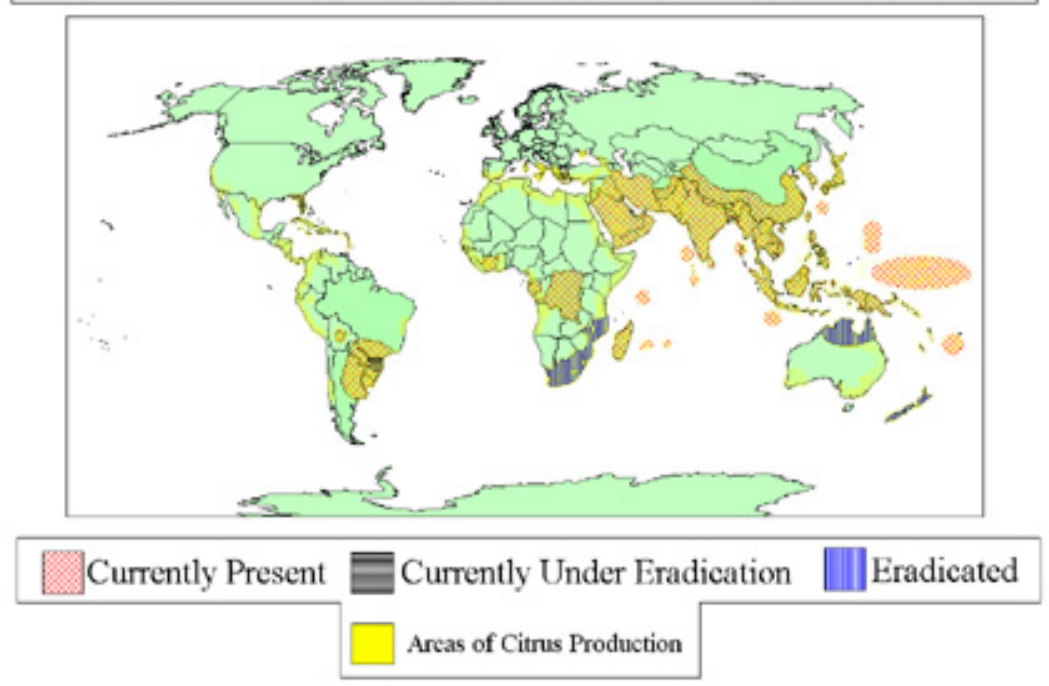

Fig. 2. Map of the geographical range of citrus canker (CC) worldwide against a backdrop of areas where citrus is grown.

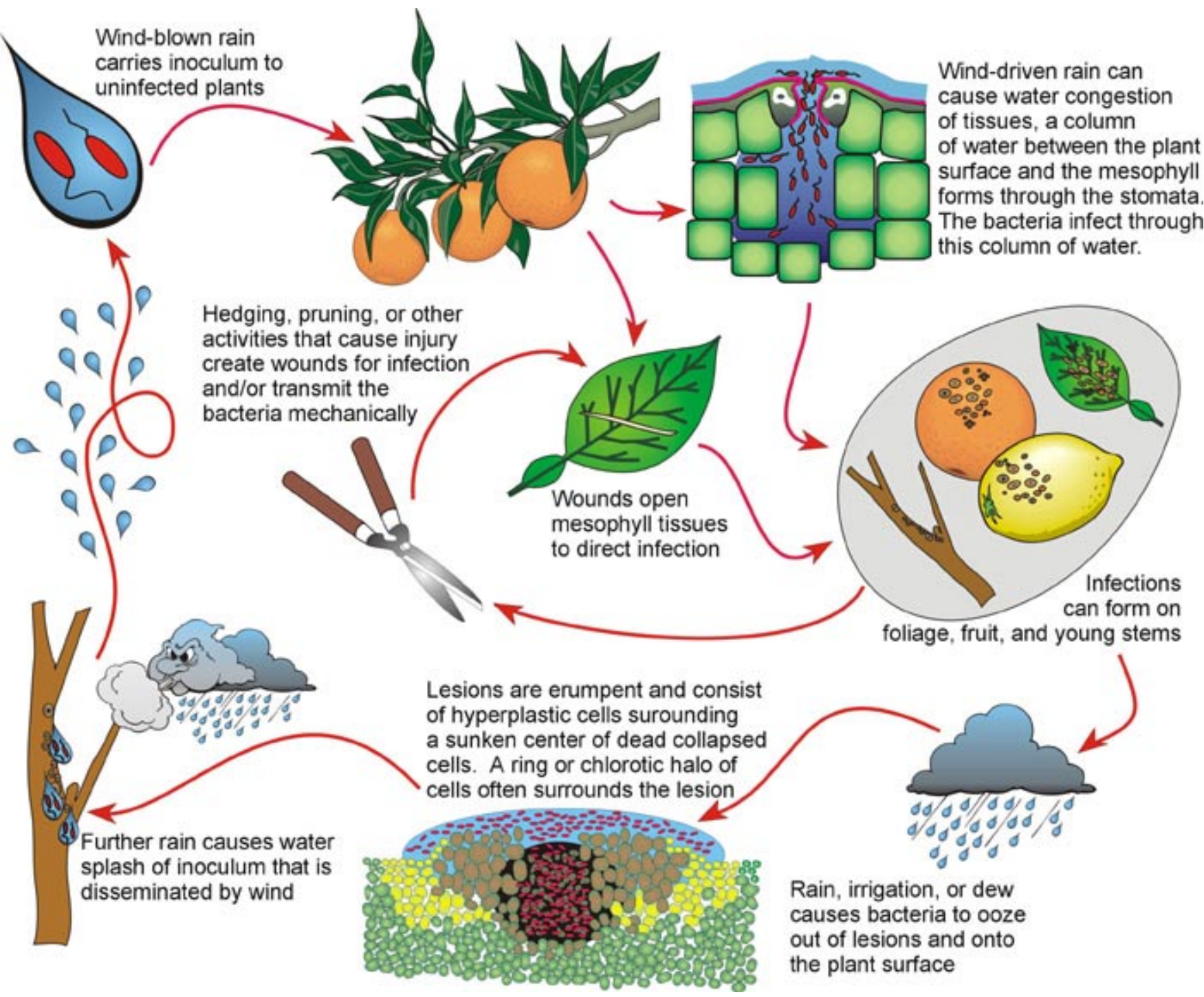

Fig. 3. The disease cycle of citrus canker. 
classified as strains of $\mathrm{CC}$, but are now either nonexistent or classified differently. The first of these was the D-strain, a disease of uncertain etiology in the Colima lime-producing area of Mexico $(45,74)$. This disease caused lesions on leaves and twigs, but not on fruit of key/Mexican lime. The presumed bacterial pathogen is no longer present in the area, and the disease is now believed to have been caused by Alternaria limicola $(51,79)$. No isolates of the presumed bacterial pathogen exist.

The second was the E-strain, formerly known as Florida nursery strain citrus canker (58), now designated citrus bacterial spot and caused by Xanthomonas axonopodis pv. citrumelo $(16,31,69)$. More background about the citrus bacterial spot disease is mentioned later.

Symptoms and infection process. The $\mathrm{CC}$ life cycle is depicted in Figure 3. All aboveground tissues of citrus are susceptible to $X$. axonopodis pv. citri when they are young, and at maximum susceptibility during the last half of the expansion phase of growth $(20,72)$. Bacterial cells ooze from existing lesions during wet weather to provide inoculum for further disease de-
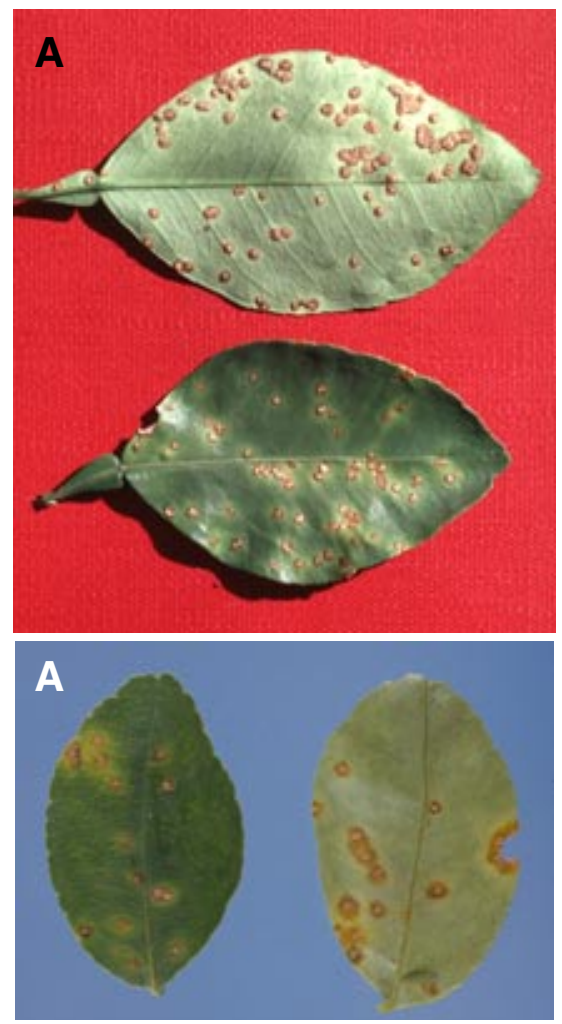

Fig. 4. Typical leaf lesions of citrus canker (CC) on upper and lower surface of grapefruit leaves, A, show the characteristic corky outgrowth in the center of the tan lesion surrounded by a chlorotic halo. Unless the infection occurs in a shallow wound, the raised tissue is apparent on both sides of the leaf. Heavy infections can cause defoliation. B, Typical lesions of CC on key lime leaves, upper and lower surface. Note ring of infection around wound. velopment (80). Like many other bacterial diseases, the pathogen enters host plant tissues through stomates $(20,33,41)$ and wounds $(41,50,77)$. The earliest symptoms on leaves appear as tiny, slightly raised blister-like lesions around 7 days after inoculation under optimum conditions. Optimum temperature for infection falls between 20 and $30^{\circ} \mathrm{C}(40)$. Under less than optimum infection and incubation conditions, symptoms may take 60 days or more to appear (44). As the lesions age, they first turn gray, then tan to brown, and a
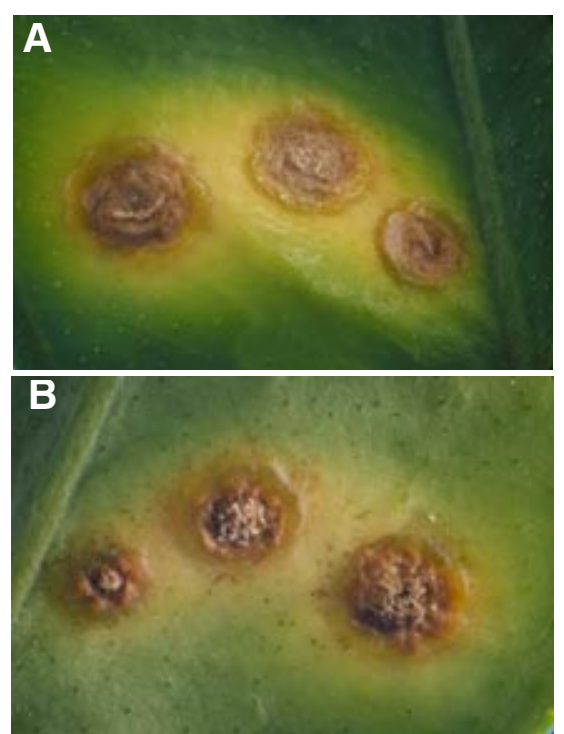

Fig. 5. A close-up view of the A, upper surface and $B$, lower surface of the same three citrus canker lesions. The raised necrotic tissue is surrounded by a water-soaked border and a chlorotic halo, normally visible on both surfaces of the lesions.

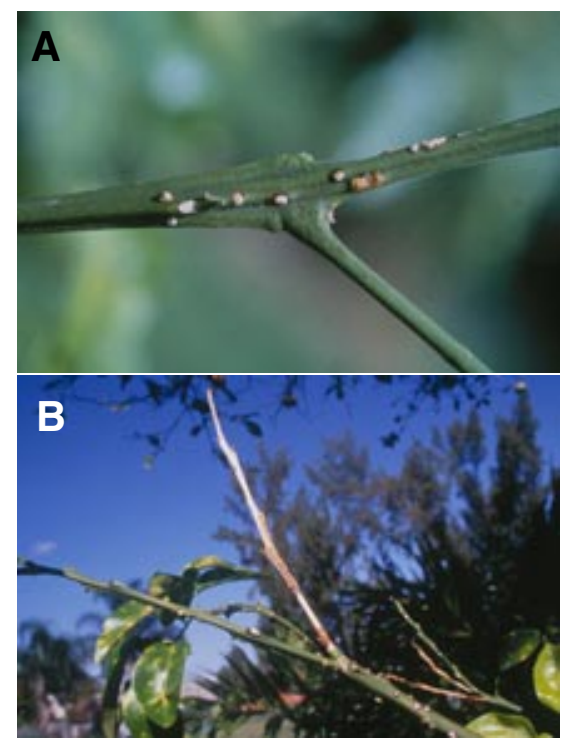

Fig. 6. A, Twig lesions are necrotic and raised, lacking the chlorotic halo. B, Defoliation and twig dieback can result from heavy infection, such as on this pummelo. water-soaked margin appears, often surrounded by a chlorotic halo (Fig. 4A and B). The water-soaked margin may disappear as lesions age, and it is not as prominent on resistant cultivars. The center of the lesion becomes raised and spongy or corky (Fig. 5). These raised lesions from stomatal infection are typically visible on both sides of a leaf. Eventually, the centers of leaf lesions become crater-like and may fall out, creating a shot-hole effect. Defoliation becomes a problem as the disease intensifies on a plant $(19,25,29)$.

On twigs and fruit, CC symptoms are similar: raised corky lesions surrounded by an oily or water-soaked margin. No chlorosis surrounds twig lesions (Fig. 6A) but may be present on fruit lesions (Fig. 7A and B). It is the twig lesions on angular young shoots that provide much of the perpetuating $X$. axonopodis pv. citri inoculum in areas where $\mathrm{CC}$ is endemic. Twig dieback (Fig. 6B), fruit blemishes (Fig. 7), and early fruit drop are major economic impacts of the disease in advanced stages. If twigs are not killed back by girdling infections, the lesions can persist for many years, causing raised corky patches in the otherwise smooth bark (Fig. 8).

As a general rule, $X$. axonopodis pv. citri is capable of naturally infecting green citrus tissues most readily while they are in the last half of expansion phases of growth. Once leaves, twigs, and fruit reach mature size and begin to harden off physiologically, they become more resistant to infection (71). Very young tissues are also re-
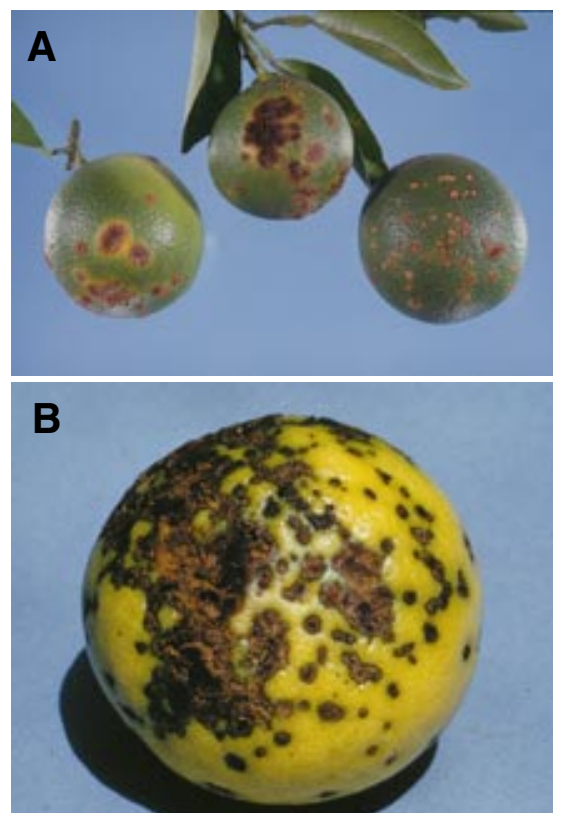

Fig. 7. Fruit lesions are unsightly raised rind blemishes that reduce the marketability for fresh consumption, result in severe market restrictions because of quarantines, and can cause premature abscission when severe. These lesions are on, A, sweet oranges and, B, grapefruit. 
sistant to natural stomatal infection but may suffer wound infections. Mature aboveground tissues can also be infected through wounds. Since the young growth provides the bulk of the susceptible tissues, vigorously growing trees are most threatened by $X$. axonopodis pv. citri. A wellmanaged citrus tree in Florida will undergo three to five growth flushes every growing season, each accompanied by a period of susceptibility.

The serpentine mines (Fig. 9A) caused by the larvae (Fig. 9B) of the Asian citrus leaf miner (Phyllocnistis citrella Stainton) (Fig. 9C), a pest first detected in 1993 in Florida (36), provide ample wounding on new growth to greatly amplify $\mathrm{CC}$ infection $(9,56,67,68)$ (Fig. 10A to C). Wounding by the Asian citrus leaf miner presents a significant new advantage for the spread of CC in Florida. Epidemiological studies of $\mathrm{CC}$ conducted in the Western Hemisphere prior to the appearance of the leaf miner $(11,12,21,26)$ underestimate current disease increase and spread, since both the incidence of wounds that serve as infection courts and the amount of inoculum produced in a lesion have increased dramatically (1).

As with other bacterial diseases, winddriven rain is the primary short- to mediumdistance dispersal mechanism for $\mathrm{CC}$ $(25,28)$. Stomatal infection is aided by windblown rain that is propelled by wind speeds of 17 to $18 \mathrm{mph}$ (64). Contaminated equipment and persons can also transmit inoculum of $X$. axonopodis pv. citri. Long-distance spread normally occurs by human movement of diseased or exposed citrus plant material or by use of equipment contaminated by diseased citrus. Strong circumstantial evidence points to occasional long-

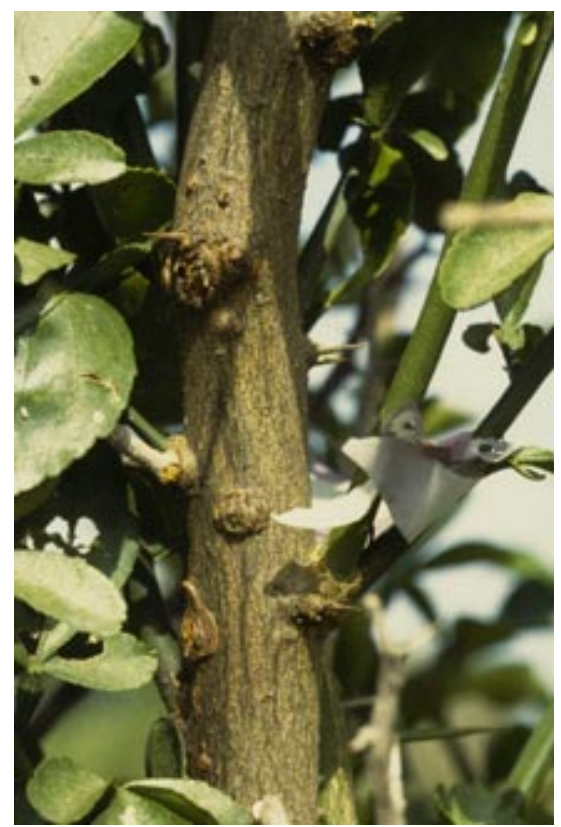

Fig. 8. Lesions persist on green twigs as they mature into branches with brown bark, leaving raised corky patches. These older lesions are on Carrizo, a citrange used as a rootstock. distance transport by unusual storm events such as tornadoes and tropical storms $(22,23)$.

$X$. axonopodis pv. citri easily persists from one growing season to the next in old lesions, especially lesions formed late in the growing season. X. axonopodis pv. citri can remain viable as long as host cells in the vicinity of the lesion remain viable, although the bacterial titer will drop considerably $(78,80,81)$. Stem lesions can harbor viable bacteria for several years. Viable bacteria were recently isolated from stem lesions on 5- to 7-year-old branches in Florida (X. Sun, unpublished data). Reports of inoculum longevity outside host tissue are inconsistent. Circumstantial evidence suggests that inoculum associated with exposed, symptomless citrus leaves can survive and remain infective for at least several months, perhaps located within older, more disease-resistant leaf and stem tissues. Attempts to culture surviving bacteria on various inanimate surfaces such as metal, plastics, cloth, and processed wood in both shade and sun indicate the inoculum dies within 24 to 72 h (35). X . axonopodis pv. citri may persist for several weeks on nonhost plant material, with some exceptional reports of longer persistence (about 8 months) in the root zone of certain grasses under eradi-
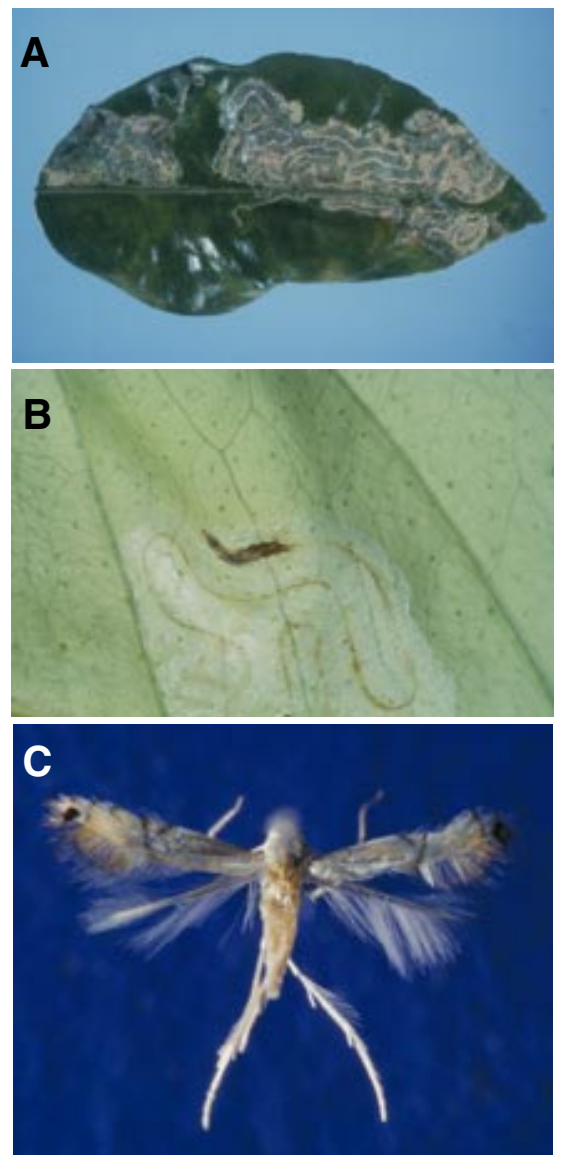

Fig. 9. A, Serpentine mines of the Asian citrus leaf miner. B, Larva in mine. C, Adult moth of the Asian citrus leaf miner. cated diseased trees in Japan $(18,54)$ and Brazil (53), although no other studies have replicated such findings. Once diseased or exposed leaves or fruit drop to the ground, the bacterial population declines to a nondetectable level in 1 to 2 months because of antagonism and competition with saprophytic microorganisms $(32,42)$. The abundant extracellular polysaccharide slime layer that encapsulates the bacterial cells (17) aids inoculum survival.

When disease is discovered in a particular location, regulatory action is based in part on how long the disease has been active there. The number of infected plants offers one clue. Infection age on a single plant offers another. Because the infection process on this perennial woody plant is well understood and must occur naturally on tissues of a certain age, it is possible to determine approximately (within a few months) the age of the lesions. If symptoms are detected on leaves of the latest flush only (the tissues most likely to be infected), the disease began only a few weeks or months ago. The expansion rate of leaf lesions is estimated at about $1 \mathrm{~mm}$ per month for the first 6 to 8 months. Leaf lesion expansion slows and stops at around this age. The susceptible period of fruit enlargement is typically 60 to 90 days after fruit set (34), so lesions on enlarging fruit can be dated based on bloom timing. Twig
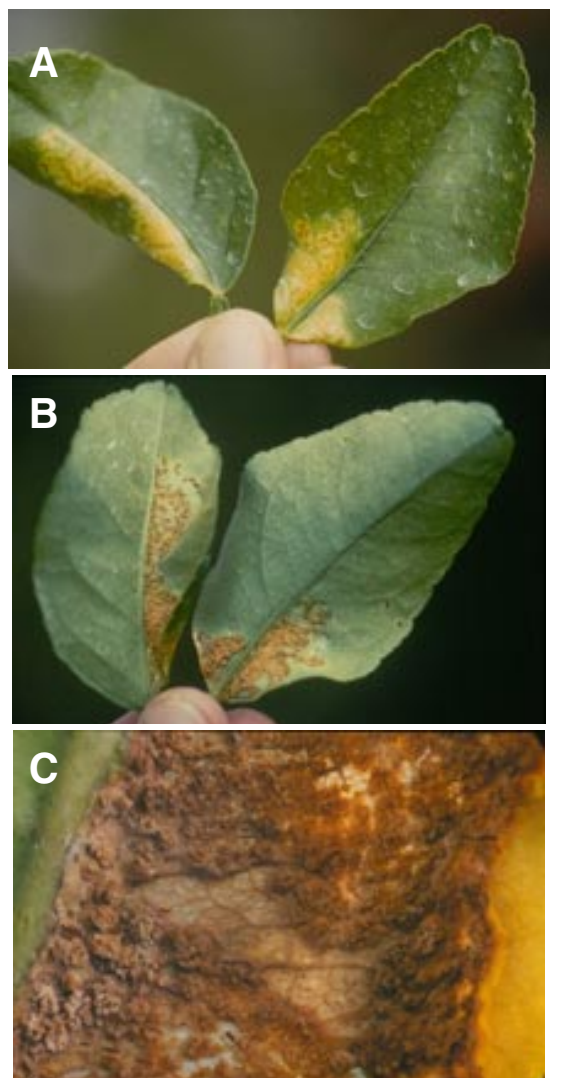

Fig. 10. Citrus canker (CC) in citrus leaf miner wounds. A, Front, and B, back of lemon leaves with $\mathrm{CC}$ infection in the mined tissues. C, Close-up view of CC lesions in mined tissues. 
lesions are generally initiated only after leaves and fruit have gone through one or more infection cycles. Appearance of fruit and twig lesions also assumes that in most cases a certain prior inoculum level must have been reached on leaves to further advance the disease. Each growth flush leaves a distinctive node on the twig; therefore the determination of twig lesion age is a matter of dating backward from the number of flushes indicated. Older lesions on bigger stems with brown bark can be dated by dendrochronological methods, keeping in mind that each growth ring records a flush and not an annual ring. One difficulty is determining the number of flushes that have occurred on that particular diseased plant within the preceding growing season(s). On trees managed for commercial production, lesion age determination is less of a challenge than on a residential tree with varying levels of typically less salubrious horticultural care.

Host range. Among citrus cultivars and rootstocks, CC is most severe on grapefruit, some sweet oranges such as Hamlin, Pineapple, and Navel; key/Mexican limes, and trifoliate orange (Poncirus trifoliata (L.) Raf.) and their hybrids that are used for rootstocks (Sidebar 1). These cultivars have proven very challenging or impossible to grow profitably in the presence of $\mathrm{CC}$ in moist subtropical and tropical climates. All other commercial cultivars of citrus, although varying in susceptibility, are susceptible enough that they must be removed in an eradication effort when diseased or exposed. Civerolo (6) lists a number of plants in the Rutaceae other than Citrus and Poncirus that can serve as hosts of $X$. axonopodis pv. citri under ex- perimental conditions or heavy disease pressure in nature. These plants would not be expected to play any significant role in CC epidemiology where the disease is endemic, but they could serve as troublesome inoculum reservoirs in an eradication or suppression program.

One complicating factor is the Asian citrus leaf miner, whose feeding activities form galleries beneath the foliar cuticle as it eats the epidermal cell layer. Cracks in the cuticle result in direct exposure of the mesophyll tissues to infection by $X$. $a x$ onopodis pv. citri, and massive lesions can result. The combination of $X$. axonopodis pv. citri and the leaf miner can lead to significant field infection even on highly resistant cultivars and species of citrus such as calamondin and kumquat (T. R. Gottwald, unpublished). Although the above relative susceptibility rankings remain valid in spite of the introduction of the Asian citrus leaf miner into Florida, all cultivars of citrus are now much more vulnerable due to the wounding caused by larval feeding. Cultivars once thought resistant enough to be easily grown in the presence of $\mathrm{CC}$ frequently have been found diseased in residential plantings. As a rule, proximity to more susceptible citrus cultivars greatly increases the chances of infection on more resistant cultivars.

In an eradication program, it is important to identify all prospective hosts of the target pest or pathogen. Recently, Kalita et al. (38) reported that goat weed (Ageratum conyzoides L.) in India serves as a host of $X$. axonopodis pv. citri. This plant is common in citrus orchards in India and is reported from isolated locations in Florida. This represents the only report of a non-
Rutaceous natural host of $X$. axonopodis pv. citri. Pathogenicity tests of $X$. axonopodis pv. citri on Ageratum conyzoides in Brazil were negative (R. Leite, personal communication), suggesting that the apparent infection of this non-Rutaceous plant may have been hypersensitivity resulting from extremely high inoculum challenges, and not true susceptibility.

\section{History of CC Worldwide}

The distribution of CC in relation to the areas of the world where citrus is grown is depicted in Figure 2. Briefly, the history of $\mathrm{CC}$ is as follows:

\section{Origin and Spread}

- Center of origin was in Southeast AsiaIndia based on herbarium specimens from India (1830) and Java (1840) at the Royal Botanical Gardens in Kew, England (6).

- By the twentieth century, CC was present in Asia/Japan, South and Central Africa, the Middle East, Australia, New Zealand, the Pacific Islands, South America, and Florida.

- CC was successfully eradicated from South Africa, Australia, the Fiji Islands, Mozambique, New Zealand, and the United States (40).

- Active eradication programs still continue in Argentina, Uruguay, Brazil, and Florida.

\section{CC in Florida, 1910 to 1994}

- First episode: 1910 (A-strain) introduced on trifoliate rootstock from Japan. CC present from Texas around Gulf Coast to South Carolina $(14,44)$. Quarantine imposed 1915. Florida groves/orchards lost 257,745 trees; 3,093,110 nursery plants destroyed in 26 counties (55). Eradication declared successful in 1933 (14). $\mathrm{CC}$ declared eradicated from the remainder of the United States in 1947. $\mathrm{CC}$ has remained a target of regulatory detection surveys of one form or another in Florida ever since.

- 1984: Bacterial leaf spot/nursery strain citrus canker discovered on citrus nursery stock (E-strain) $(59,75)$. Disease resembles CC, although lesions are flat, not raised $(15,30)$. Eradication attempted $(58,60)$. Twenty million citrus plants destroyed, total program costs and plant losses $=\$ 94$ million. Research during eradication reveals pathogen is quite variable, widely distributed in state, not as virulent as CC pathogen, origin unknown, not found outside Florida, probably not introduced but adapted from existing populations of Xanthomonas in Florida to cause disease in citrus nurseries $(31,69)$. Progressive deregulation through 1987, complete deregulation by 1990 .

- Second episode: 1986 to 1994 (Astrain). CC found in residential citrus in Tampa Bay area of west central Florida, 
later in commercial citrus nearby. Eradication by removal of infected trees plus exposed trees within $38 \mathrm{~m}$ (125 ft) (72), occasionally by pruning or herbicide treating to kill back to brown wood $(5,60,69)$. 87,741 commercial citrus on 240 ha (593.5 acres) destroyed, 600 residential trees removed. Program cost $=\$ 27$ million. Official declaration of eradication in 1994. Most scientists believe $X$. axonopodis pv. citri was reintroduced in the early to mid-1980s, but a few speculate that this outbreak might have resulted from perennial holdover from $1910 \mathrm{X}$. axonopodis pv. citri introduction.

\section{CC in Florida, 1995 to the present}

Figure 11 indicates the various residential and commercial $\mathrm{CC}$ infection sites statewide starting in 1995, the date when the disease was first detected in the area, and the isolate of $X$. axonopodis pv. citri detected there. An obvious pattern is revealed: the residential infections in southeastern Florida have provided the great majority of the inoculum causing $\mathrm{CC}$ in the rest of the state. It is here that the eradication effort is meeting its greatest challenge. A chronological presentation and analysis of the major events in both commercial and residential citrus so far follows. Relevant statistics for each year of the program since 1995 (location, size of quarantine area, number of trees destroyed, and budget) are also given.

Late 1995 through 1996. The latest era of CC in Florida commenced in late September of 1995, when citrus canker was discovered on residential citrus near the Miami International Airport in MiamiDade County. The infection was discovered by an employee of the FDACS-DPI while conducting routine fruit fly trapping in the area. At the time of discovery, the lesions were judged to be about 2.5 years old (T. R. Gottwald, unpublished data). The infested area was preliminarily estimated to be about 3,626 ha $\left(14 \mathrm{mi}^{2}\right)$, but after a more careful inspection, that area expanded to about 12,950 ha $\left(50 \mathrm{mi}^{2}\right)$ containing thousands of diseased citrus. An eradication program was initiated immediately. Although one of the options considered at the outset was the removal of all citrus from the infested area, this action was considered too extreme. Instead, the offensive was launched only against the infected and immediately adjacent citrus. Genetic fingerprinting of the isolate of $X$. axonopodis pv. citri causing $\mathrm{CC}$ in the Miami area revealed that the pathogen was recognizably different from the archived isolates from the 1986 to 1992 outbreak in the Tampa Bay area (61).

The enormous amount of international travel and commerce in the Miami area is a significant potential source of exotic pest introductions of this kind (82). As is usually the case, there is no firm evidence of how the pathogen arrived in Florida at this time. Hurricane Andrew hit South Florida in 1992, about the time the disease made its appearance, and some have speculated about that storm's possible role in the introduction. Several other exotic pests appeared in South Florida at about the same time: the Asian citrus leaf miner (Phyllocnistis citrella Stainton), the brown citrus aphid (Toxoptera citricida (Kirkaldy)), and the Asian citrus psyllid (Diaphorina citri Kuwayama).

The initial approach to eradicating $\mathrm{CC}$ in the residential neighborhoods of Miami in 1995 called for removal of all infected trees, and pruning back to brown wood all exposed trees within a $38-\mathrm{m}(125-\mathrm{ft})$ radius of the infected tree. This procedure was used with success in certain instances during the 1986 to 1994 eradication campaign on the Gulf Coast near Tampa, and the federal and state regulatory agencies were willing to attempt preservation of exposed trees if at all possible and practical. The prospects for the success of this "hatracking" or "buckhorning" process are based on the knowledge that all green aboveground citrus tissues are susceptible to the pathogen. It was hoped that most exposed trees could escape infection and be salvaged if no susceptible tissue remained. After about 1 year operating under these guidelines, it was clear that the number of hatracked exposed trees that eventually became infected with CC was approaching 35 to $40 \%$ after a few inspection cycles - far too many to warrant continuing the procedure. The reinfection was likely due to the generally high inoculum load in the vicinity of hatracked trees. Inoculum levels remained high because not all properties with infected citrus in an area could be dealt with simultaneously due to access problems. Furthermore, hatracking eventually creates another biological risk in that once all susceptible tissues are removed from a tree, a period of high susceptibility follows within 3 to 8 weeks as a new vulnerable growth flush emerges over the entire canopy. Based on these findings, the decision was made at the end of 1996 to remove rather than hatrack all exposed trees within $38 \mathrm{~m}(125 \mathrm{ft})$ along with the infected trees. During this first 15 -month period, CC had spread from an initial area of about 3,626 ha $\left(14 \mathrm{mi}^{2}\right)$ at the start of the program to cover 23,569 ha $\left(91 \mathrm{mi}^{2}\right)$ within a 68,635 -ha $\left(265 \mathrm{mi}^{2}\right)$ quarantine area. The work force, initially 60 persons for the entire project, had risen to 233 . Program costs for the period were about $\$ 3$ million.

1997. The next year of the program met with only limited success, mostly because a lack of resources and understaffing made it impossible to meet survey frequency schedules. Removal rather than hatracking of exposed trees was clearly advisable from a biological standpoint, but this approach was not popular with the citizens of the area. The disease had spread to cover almost 36,260 ha $\left(140 \mathrm{mi}^{2}\right)$ in a quarantine area that extended over 93,499 ha (361 $\mathrm{mi}^{2}$ ). The total workforce had swelled to 491. More than 1.4 million properties had been inspected, with citrus destruction on more than 34,000 of these properties. By the close of 1997, the annual budget for the program was $\$ 8.7$ million.

An additional setback occurred in May 1997, when CC was discovered again in commercial citrus in the west central Florida area on the Gulf Coast. This marked the beginning of the involvement of commercial citrus with $\mathrm{CC}$ in the current program, and it appears to have initiated (or in this case probably persisted) in noncommercial citrus somewhere in the area. By the time this find was initially delimited, several groves and a few residential citrus trees in the vicinity were already infected. Genetic fingerprinting (restriction fragment length polymorphism) of the isolate active in the west central Florida area compared with the one active in the southeastern Florida area revealed recognizable differences between the two (63). Furthermore, the isolate in west central Florida appeared to be essentially the same as the one that had been active in 1986 to 1992 , leading to the conclusion that the earlier outbreak had not been completely eradicated in the second campaign. By the end of 1997, the tree losses stood at 600 commercial trees with 36 more hectares (90 acres) awaiting destruction, and over 700 trees in residential areas. The west central Florida quarantine area CC

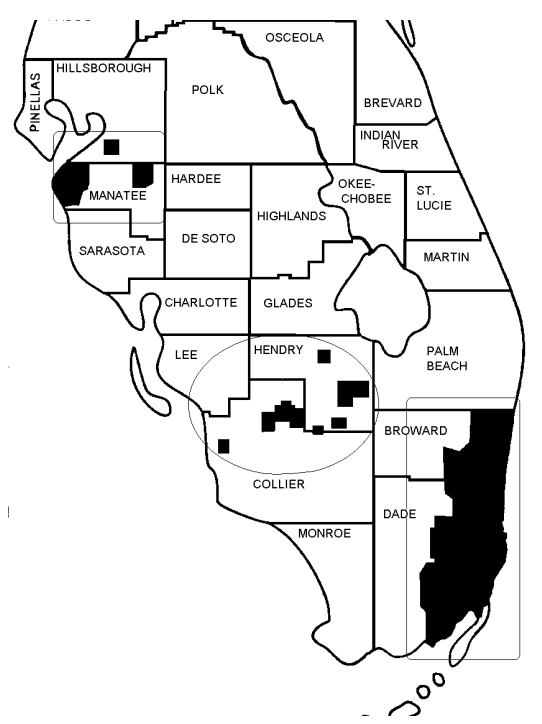

Fig. 11. Map of the current extent of citrus canker (CC) in Florida as indicated by quarantine zone locations (black areas). The quarantine zones fall into three main areas: southeast Florida, southwest Florida, and west central Florida near Tampa Bay. The Miami genotype is responsible for all the CC outbreaks in the southeast and southwest zones, and for several in the Tampa area. 
workforce consisted of 50 persons with a budget of $\$ 3$ million per year.

Removal of exposed citrus, whether commercial or residential, has fostered a range of responses from willing acceptance to outright opposition, so that overcoming skepticism is a frequent duty. This is especially true if the diseased tree that doomed the exposed tree is on someone else's property. Part of this sentiment lies in the failure to understand why an eradication campaign is warranted against a plant disease that itself is not fatal to citrus. It has always been difficult to convey to the layperson that $\mathrm{CC}$, although not fatal to its host, is actually more harmful in the long run than a quickly fatal disease because it gradually debilitates the tree while serving as an inoculum reservoir to infect neighboring citrus. The lesson is more quickly learned by those making a living by growing citrus. If commercial citrus were the only arena in which the eradication effort needed to operate, the goal could be achieved much more easily. CC not only saps citrus tree fruit productivity, it even ruins the more susceptible varieties aesthetically, detracting from the shade and ornamental values important to the residential citrus grower.

1998. In early 1998, the Florida Commissioner of Agriculture and the CCEP declared a moratorium on removal of exposed citrus to allow a period of study on urban and suburban epidemiology of CC. Public sentiment was growing increasingly negative, mainly because of the unpopular tactic of removing exposed trees. All previous epidemiological studies concentrated on disease spread in commercial plantings of a density around 100 to 225 trees per acre. In the suburban setting, tree density is less than 10 per acre, with scattered tree placement, mixed cultivars, and a wide range of tree ages. In general, most residential citrus have less vigor (and are thus presumably more resistant) than commercial citrus, with some notable exceptions. Also, more importantly, previous studies on the spread of CC did not include the exacerbating effects of the Asian citrus leaf miner. The results of this urban-suburban study were to be used to derive an appropriate exposure zone that would dictate removal of exposed citrus in this presumably different environment. Analysis of data collected over the next 12 to 18 months revealed that a much larger exposure radius than $38 \mathrm{~m}(125 \mathrm{ft})$ was indicated. In fact, the data supported removal of exposed citrus within a radius of $580 \mathrm{~m}$ (1,900 feet) of a focal tree in order to have a $95 \%$ chance of eliminating all of the subsequent infections that would arise from inoculum dispersal from the focus $(24,27)$. This $580-$ $\mathrm{m}(1,900-\mathrm{ft})$ exposure radius has now become the general rule for identifying exposed trees unless mitigating circum-

\section{Citrus Canker Eradication Program risk assessment procedures, level 1 and} level 2

\section{Risk Assessment Procedures-Level 1}

Does a general area-wide risk assessment apply?

Is a specific risk assessment for this property warranted?

Qualification checklist (6 yes answers qualify for a level 2 risk assessment)

1. Is canker absent?

2. Is disease incidence low?

3. Is the disease monocyclic?

4. Is this citrus isolated geographically from other citrus?

5 . Are good sanitation practices employed?

6. Is survey unhindered?

7. Does property have adequate security?

Risk Assessment Procedures-Level 2

Factors considered

Residential or commercial

Cultivar/susceptibility

Tree size and age

Size of block

Tree spacing

Horticultural condition

Disease distribution in population

Weather events

Windbreaks present

Human activity

Lesion age and distribution on host

Disease severity

Tissues infected (leaves, fruit, twigs)

Leaf miner activity

Program resources

Access/security

Compliance and timeliness

Management practices

Other citrus nearby

Other diseased citrus nearby stances can be identified.

Where mitigating circumstances are present, a two-level process of risk assessment is used to customize the regulatory actions precipitated by the discovery of $\mathrm{CC}$ in an area (13) (Sidebar 2). Level 1 determines if a full-scale risk assessment is actually warranted, or whether the default action is appropriate. Level 2 addresses specific parameters leading to a detailed recommended regulatory action for that particular incident.

During the first 12 months of this study period, the area in Miami-Dade County containing infected citrus grew to 51,800 ha $\left(200 \mathrm{mi}^{2}\right)$ and began to encroach into an additional 4,403 ha $\left(17 \mathrm{mi}^{2}\right)$ of Broward County to the north. The quarantine area was on the verge of expansion to 129,500 ha $\left(500 \mathrm{mi}^{2}\right)$, and the budget had reached $\$ 9.5$ million. Over 100,000 diseased and exposed residential citrus trees in this area had been destroyed.

Simultaneously, the 1998 west central Florida quarantine area eradication effort was working within a 9,842 ha $\left(38 \mathrm{mi}^{2}\right)$ quarantine area that was on the verge of expansion to $15,540 \mathrm{ha}\left(60 \mathrm{mi}^{2}\right)$ because of disease occurrence just outside the boundaries. Over 324 ha (800 acres) of commercial citrus, some of it abandoned, had been destroyed in this area because of CC infection or exposure, with 7 ha (18 acres) still awaiting destruction at year's end. Additionally, a total of 750 diseased and exposed residential citrus were removed.

1999. After the third concurrent outbreak of CC was discovered in June 1998 in a commercial grapefruit orchard in the Immokalee area of southwestern Florida, $\mathrm{CC}$ was discovered in an isolated rural residential area nearby a year later. Several more outbreaks of $\mathrm{CC}$ were detected in commercial orchards in southwestern Florida quarantine zones in 1999. In June 1999, the disease was detected in a commercial orchard in the west central Florida quarantine area.

All pathogen isolates from new locations are routinely genetically characterized to help identify the source(s) of inoculum. With the exception of the isolates in the west central Florida quarantine area (the holdovers for the 1986 to 1992 program) and the presence of both Miami and Manatee isolates in the outbreak on the northern edge of the west central Florida quarantine area, all other $\mathrm{CC}$ isolates in Florida are identical to the pathogen initially discovered in Miami in 1995 (Fig. 11). This supports the idea that persons coming out of the Miami area (or subsequently infected areas) are transmitting inoculum to initiate disease in these new areas a long distance away. Several significant catastrophic and tropical storm events have also impacted the infested areas over the last 8 years in which CC has evidently been present in South Florida $(22,23)$. Such tornadoes, tropical storms, and hurri- 
canes undoubtedly have the potential to move inoculum over great distances, too. However, the fact that intervening uninfected citrus exists between these outposts of infection makes the case seem stronger for human involvement in most longdistance inoculum dispersal. This assumes that a disease gradient of some form should exist between source and destination of inoculum distributed by weather events, but this may not be a safe assumption. It is frankly impossible at this time to be absolutely certain how long-distance movement of inoculum occurs.

In late 1999, diagnosis of $\mathrm{CC}$ in the commercial Persian lime production area in South Miami-Dade County immediately south of the southeastern Florida quarantine area lead to the destruction of just under half of the approximately 1,788 ha $(4,000$ acres $)$ of lime in the area due to infection or exposure. Although the industry had remained apparently disease free for over 4 years while $\mathrm{CC}$ flourished in the residential citrus 15 miles to the north, the pathogen eventually found its way into the area, probably via human activities. The oldest infections were detected in especially susceptible cultivars of pummelo being grown in the immediate vicinity of commercial limes. Once again, the risk of $\mathrm{CC}$ associated with growing more suscep-

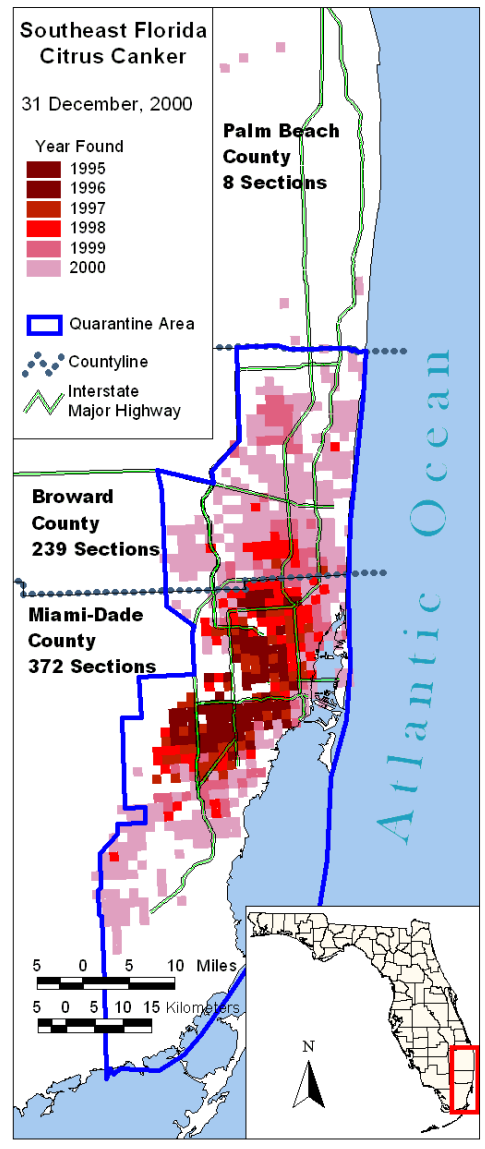

Fig. 12. Chronological depiction of citrus canker (CC) spread in southeast Florida, 1995 to present. tible citrus near a relatively resistant citrus cultivar (Persian limes) was plainly demonstrated.

2000. The eleventh commercial orchard was discovered with canker in the southwestern Florida quarantine area in April. In May, an apparently different genotype of $\mathrm{CC}$ was discovered on key/Mexican lime in two communities in Palm Beach County just north of the southeast Florida quarantine zone boundary (76). The discoveries were made by survey teams assigned the task of "sentinel survey" (24). This recently adopted technique identifies an evenly dispersed grid of existing, highly susceptible grapefruit and key/Mexican lime to be inspected monthly in the quarantine perimeter areas to serve as an early warning system of CC spread into the area. The idea is based on the consistent observation that when $\mathrm{CC}$ moves into a new area, it inevitably infects these susceptible varieties first. The new canker pathogen genotype, although exhibiting typical CC symptoms, was noteworthy in that in spite of having been present in the area on key/Mexican lime for many years, it had not spread naturally to nearby susceptible grapefruit. This discovery was reminiscent of previous discoveries of key/Mexican lime-specific isolates of $\mathrm{CC}$ around the world (84), and so prompted genetic, host range, cultural, and physiological characterizations that did indeed reveal significant differences from the typical Asian strain. This observation reinforces the contention that visual diagnosis in the field is being done by competent and observant persons. The question arose as to whether previous key/Mexican lime canker outbreaks may have also been due to this pathogen with a restricted host range. Pathogenicity and host range tests on representative isolates from previous detections on key/Mexican lime in the southeastern Florida quarantine zone where canker has been active for several years showed them to be typical CC, not the new strain. It is significant from both a biological and regulatory perspective that the key/Mexican lime infected with the unusual strain was in the yard of a family who recently had arrived from India and who could not or would not reveal the source of the plant. Interestingly, the iso- late discovered in Florida did not match any of the key lime-specific strains studied by Vernière $(76,84)$.

2001. A chronological depiction of the spread of $\mathrm{CC}$ in just the southeastern Florida quarantine area is presented in Figure 12. Until the disease is brought in check in this area, the hope of defeating $\mathrm{CC}$ in the southwestern and west central Florida quarantine areas is dim. Table 1 presents cumulative statistics to date for the three main quarantine areas.

The sentinel areas in Palm Beach County where four $\mathrm{CC}$ infections and 49 key/Mexican lime-specific CC infections have been found technically are still outside the northern boundary of the southeastern Florida quarantine zone, but are receiving regular surveys as if they were. Some sections where the outbreak originated in 1995 in southeastern Florida are essentially now citrus-free, i.e., all citrus has been eliminated because of either infection or exposure. Gottwald et al. (24) have presented a graphic depiction of the impact of enacting the new 580-m (1,900$\mathrm{ft})$ rule for determining $\mathrm{CC}$ exposure.

The CCEP in the southeastern Florida quarantine area has expended approximately \$200 million so far and currently employs a workforce of approximately 1,565 persons. This is a temporary high level considered necessary to meet urgent survey goals and accomplish timely tree removal in this area of very high disease incidence. The recent adoption of FDACS Canker Image Viewing Application, Version 6.0 (Image API, Inc.) and ArcView GIS 3.2 (1999 Environmental Systems Research Institute, Inc.), and even more recently PICS 1.0 (Pest Incident Control System, Infinity Software Development, 2000) software has made the enormous tasks of database management, information organization and availability, and mapping achievable. The smaller programs in west central and southwestern Florida operate with budgets of about $\$ 3$ million and workforces of about 120 persons each. New offices in CC-free areas are employing 20 to 30 persons each to conduct statewide citrus surveys in residential, commercial, and nursery citrus.

Regular updates on program activities are posted on the Internet at the web site of

Table 1. Citrus Canker Eradication Program (CCEP) statistics in the three geographic areas where citrus canker occurs in Florida, 1/2001

\begin{tabular}{lcccc}
\hline $\begin{array}{l}\text { Geographic area } \\
\text { (counties) }\end{array}$ & $\begin{array}{c}\text { Quarantine } \\
\text { areas (no.) }\end{array}$ & $\begin{array}{c}\text { Quarantine } \\
\text { area(s) }\left(\mathbf{m i}^{2}\right)\end{array}$ & $\begin{array}{c}\text { Residential } \\
\text { trees removed }\end{array}$ & $\begin{array}{c}\text { Commercial } \\
\text { trees removed }\end{array}$ \\
\hline $\begin{array}{c}\text { Southeast Florida (Dade, } \\
\text { Broward, Palm Beach) }\end{array}$ & 1 & 1,000 & 568,807 & 290,718 \\
$\begin{array}{c}\text { Southwest Florida } \\
\text { (Hendry, Collier) }\end{array}$ & 6 & 159 & 2,299 & 532,281 \\
$\begin{array}{l}\text { West central Florida } \\
\text { (Manatee, Hillsborough) }\end{array}$ & 3 & 162 & 5,144 & 100,811 \\
Total & 10 & 1,321 & 576,250 & 923,810 \\
\hline
\end{tabular}


the Florida Department of Agriculture and Consumer Services.

\section{Regulatory Requirements in Quarantine Areas}

The regulations that apply to both commercial and/or residential citrus growers in $\mathrm{CC}$ quarantine areas are fairly straightforward (61). These regulations also apply to anyone who may come in contact with citrus in the course of their work, such as contract mowers, fertilizer and herbicide applicators, fruit buyers, irrigation equipment service persons, lawn maintenance crews, meter readers, and so on. No citrus plant material is permitted to leave the area, except under circumstances that may be prescribed by the CC Risk Assessment Group and authorized by an official written Compliance Agreement. Sanitation procedures using sprayable quaternary ammonium detergent disinfectants are outlined for persons or equipment that may come into contact with citrus in the quarantine area. Personnel and equipment sanitation (of anything that comes in contact with citrus plant material) is prescribed between properties in residential areas, and on both entering and leaving blocks or properties in commercial citrus. As of 1 April 2000, sanitation procedures were mandatory statewide, with violations punishable by a fine of up to $\$ 5,000$. No citrus propagation or replanting is permitted in the quarantine area. All waste citrus plant material generated within the quarantine area for whatever reason must be disposed of by the CCEP or according to CCEP instructions. Waste is either burned in place, where this is feasible and safe, or taken by covered conveyance to an incinerator or a sanitary landfill. A carefully controlled and monitored system of closed vessel composting is currently under consideration as another alternative method of disposal of inoculum-laden waste citrus plant material.

Harvest and transport of commercial citrus fruit within quarantine zones is also strictly regulated. Within 30 days before harvest, an orchard or block must be inspected and certified CC-free. Fruithauling trailers must be covered in transit, and the trailer must be cleaned out at the receiving facility to remove any debris that might carry undetected inoculum. Bin boxes that carry fruit must be decontaminated. Rules also specify how and where to dispose of debris, and how equipment and workers within groves are to be decontaminated. Fruit must be treated at the packinghouse with sodium orthophenyl phenate (SOPP) or a chlorine wash, and it cannot be shipped to another citrus producing area. Based on risk assessment, fruit may also be harvested under strict guidelines from orchards that have a history of CC. In such circumstances, the fruit must be decontaminated with an approved product such as chlorine at the source, covered, transported to a processor (fresh marketing is prohibited), and all pickers and equipment are subject to very strict sanitation requirements.

Full rules and regulations regarding $\mathrm{CC}$ in Florida are available on the Internet at the web site of the Florida Department of Agriculture and Consumer Services.

\section{How Surveys and Diagnoses are Conducted}

Most CCEP personnel are assigned survey duty inasmuch as this is the program's biggest responsibility. It is vitally important to train these individuals well, not only because of the fundamental importance of their technical expertise, but also because they constitute the bulk of the public interface and serve as ambassadors of the program. Surveyors are trained to locate and identify citrus species and cultivars, then carefully examine them for lesions that suggest CC. In the residential areas, their tasks require walking door to door to visit each property in their assigned area. Surveyors must be courteous and eventempered at all times, able to diffuse hostile situations that may arise while still dispatching all their assignments with adherence to every detail.

Survey activities in the quarantine areas are scheduled according to risk, mainly how much disease activity is in the area and where the zone fits into the current disease spread picture. Maintaining the interval between surveys becomes challenging as quarantine areas expand and personnel needs increase. The initial databases for planning residential survey activities were provided by the local utility companies, while ownership of commercial citrus in rural areas was determined using property records at the tax assessor's office. Weather events that might move inoculum into areas outside the quarantine zone prompt biometric detection or sentinel surveys in the predicted direction of movement. Shorter inspection intervals of 30 to 60 days are scheduled for (i) areas on the edge of the quarantine zones, (ii) where disease incidence has been high and plenty of susceptible hosts remain, (iii) where chances for movement of inoculum are good, and/or (iv) where access is unimpeded. Longer inspection intervals of 90 to 180 days are used (i) in lower risk areas such as in the middle of quarantine zones where most citrus is already lost to CC, (ii) where the disease is absent to light and host plants few, (iii) where risk of inoculum movement is low, and/or (iv) where access is problematic.

The Florida citrus inspection program has been expanded so that all citrus statewide receives an annual inspection. Commercial plantings will receive a routine inspection tree by tree, while residential areas with citrus will be monitored using a sentinel tree network as described above. This program has immediate utility for $\mathrm{CC}$ detection, but also targets a wide range of other citrus diseases and pests. Wherever a surveyor encounters citrus lesions that are the least bit suspicious, they are to mark the suspect tree with white paint and record the location on data sheets that will be electronically scanned to provide a database for each property in the area. This action then initiates a visit from one of CCEP's field plant pathologists.

A smaller group of field personnel are trained more extensively to serve as field CC diagnosticians. These persons, nominated from the ranks of the experienced survey crews, are given extensive training $(40 \mathrm{~h})$ in basic plant pathology, citrus diseases, and CC biology followed by practical supervised experience in the field. CC symptoms are unique, making it possible to diagnose the disease with certainty by visual inspection in almost all cases in the field. Diseased trees are marked with red paint; citrus plants that are exposed within $580 \mathrm{~m}(1,900 \mathrm{ft})$ are marked with yellow paint. CC-symptomatic plant samples from each new section in the Section-TownshipRange grid receive a lab diagnosis which includes a pathogenicity test. In rare instances where symptoms are not distinctive or plentiful enough to diagnose in the field, that sample is also sent to the Plant Disease Quarantine Facility of the FDACS-DPI in Gainesville for lab diagnosis. A collection of CC pathogen isolates is being kept for further study and comparison to other isolates from around the state and other CCinfested areas around the world. In addition to pathogenicity testing, selected further testing may be conducted, including:

- serological testing (either at DPI or performed by Agdia, Inc., Elkhart, IN);

- genetic typing using PCR and Southern blotting (performed by Dean Gabriel, University of Florida, Gainesville, and more recently in the Advanced Diagnostics Laboratory at FDACS-DPI);

- MIDI fatty acid profiling (performed by Jeff Jones, University of Florida); and

- identification using DNA probes (performed by John Hartung, USDAARS, Beltsville, MD).

Once the disease in a residential area is confirmed by either field or laboratory diagnosis, the diseased trees marked with red paint and the exposed trees marked with yellow paint are cut down and removed by contract commercial tree removal crews who are overseen by CCEP personnel. The lag time between diagnosis and removal is ideally less than 1 week, but logistics sometimes extend that interval. The 580-m (1,900-ft) exposure radius is inscribed by ArcView computer software, and all citrus on properties identified within the exposure zone are marked with yellow paint for removal. These cutting crews receive daily assignments from the CCEP and are paid by the number of trees they are instructed to remove and dispose of, currently about $\$ 97$ per tree. Diseased and exposed trees are cut down at ground 
level, starting with the diseased trees at the center of the zone. Diseased and/or exposed citrus plant material is hauled to curbside for chipping and loading, or loading in pieces, then hauled to a landfill or incinerator in a covered truck (Fig. 13A to $\mathrm{C})$. For the first 3 years of the eradication program, a dose of triclopyr herbicide (Garlon 4 or Brush-B-Gon formulation) was placed on the cut stump to discourage sprouting from the root system, a common phenomenon with citrus. Infection of root sprouts by the $\mathrm{CC}$ pathogen can significantly hinder the progress of the eradication campaign. A recent policy change now calls for mechanical stump grinding instead of the herbicide treatment, thereby avoiding any controversy over herbicide use on private property. In the commercial setting, diseased and immediately adjacent trees are initially burned in place using a portable flame-thrower. Next, both diseased and all exposed trees (whole trees, both tops and roots) are pushed and burned in a central location in the cleared area (Fig. 14A and B). This is followed by regular cultivation of the soil as needed in the cleared area to eliminate root sprouting.

\section{Logistical Issues}

A large workforce and many vehicles are required to regularly inspect small parcels of private property in residential neighborhoods. On average, a square-mile section of residential area in urban southeastern Florida contains ca. 2,000 separate parcels, each of which will need regular inspection for citrus hosts and for CC. About half of the properties will have some citrus growing on them, although in some communities the ratio is closer to one in three. Those that have citrus usually have two to three plants per property. This works out to a density of less than 10 citrus trees per acre. Each survey team can effectively inspect about 30 to 40 parcels a day, working an 8-h day, 5 days per week, including transportation time to and from the assigned work area. With reductions in survey efficiency for down time caused by rain, training time, and property access delays, survey efficiency drops to about 1.78 sections per year per person for a single inspection visit. Access to properties to allow inspection on a weekday can be around 80 to $85 \%$ on a good day. In order to improve that percentage, Saturday work crews are required. CCEP personnel always make an effort to contact anyone at home before entering a property. If there is no one home and the yard is accessible, the necessary inspection will be conducted and forms left at the door to explain what was done and found. If the property is inaccessible because of owner refusal, locked gates, guard dogs, etc., an effort is made to schedule an appointment at a more convenient time. In instances where access is a chronic problem, local law enforcement officials are called in to accompany the survey crew as they discharge their duties. All residential field work, whether for survey or field disease diagnosis, is done in teams of at least two persons, one of whom must be fluent in Spanish in the many areas of South Florida where this is the predominant language.

In commercial citrus orchards, inspection surveys are much more efficient. In a well-maintained property with mowed middles between rows and average sized trees, a 10-person crew can survey approximately 40 acres per day, placing one person in each row to inspect the sides of the trees facing that row. It is important to note that every time CC appears, survey resource needs jump dramatically. Even a shortened survey interval from 120 days down to 30 to 45 days requires three to
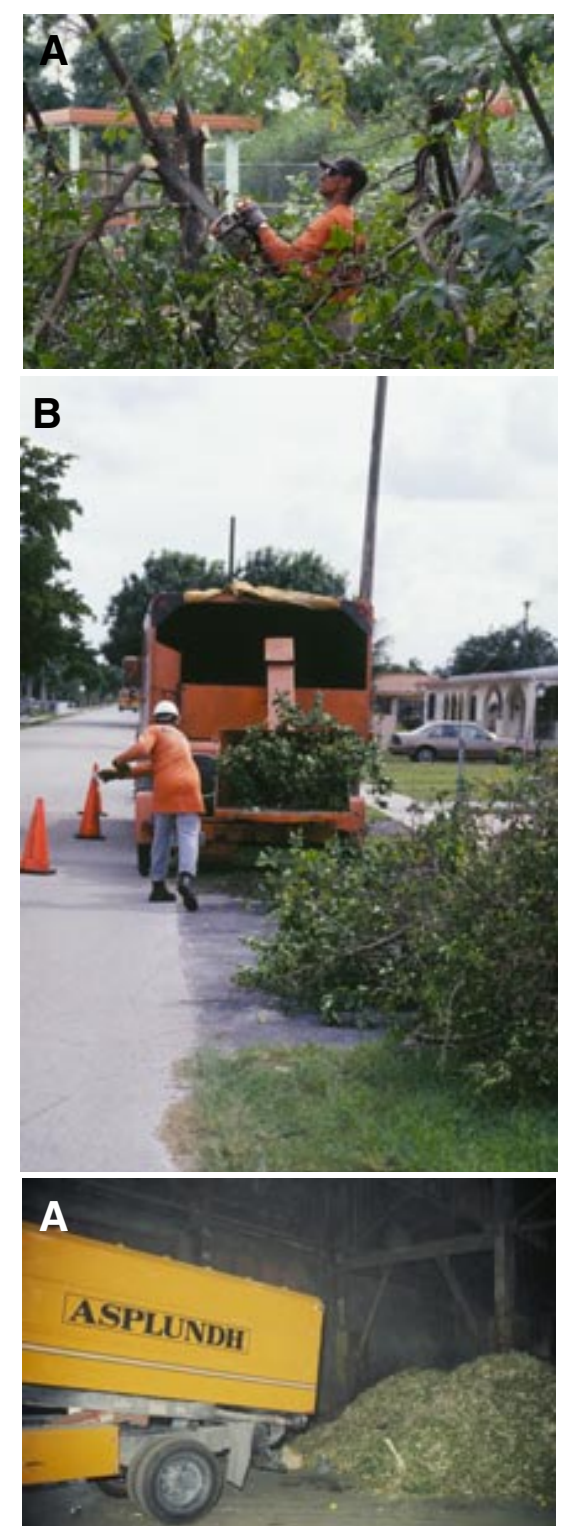

Fig. 13. A, Cutting, B, chipping, C, hauling, and dumping at the incinerator of citrus material removed from a residential setting because of infection or exposure to citrus canker. four times the amount of surveyors and support equipment. Because field diagnosticians dispatched full time are impractical in the commercial setting, when CC suspicious symptoms are encountered in commercial citrus, a specific site visit is scheduled with a plant pathologist and samples are collected for processing in the Plant Disease Quarantine Lab in Gainesville.

\section{Public Relations Issues}

Plant pathologists seldom struggle with public relations issues and generally have limited direct public interface. In the CCEP, a positive public perception of plant pathology is very difficult to attain because the initial encounter results in the loss of private property (diseased or exposed citrus) that has essentially become a public nuisance. It is important that our profession put its best foot forward in such an inherently disagreeable activity.

Compliance with plant health regulations is engendered by trust. How can the general public be convinced to trust the judgment of regulatory plant pathologists whom they do not know, scientists who have little or no prior exposure in the public arena? Public relations initiatives are almost intuitively received poorly by a small segment of the population that consider all such activities by a government agency as a slick manipulation of facts and promotion of half-truths. This public policy role is not something for which an advanced degree in plant pathology normally prepares a plant scientist, and the consensus among the plant pathologists embroiled in this work is that the unpleasant aspects often outweigh the fulfilling
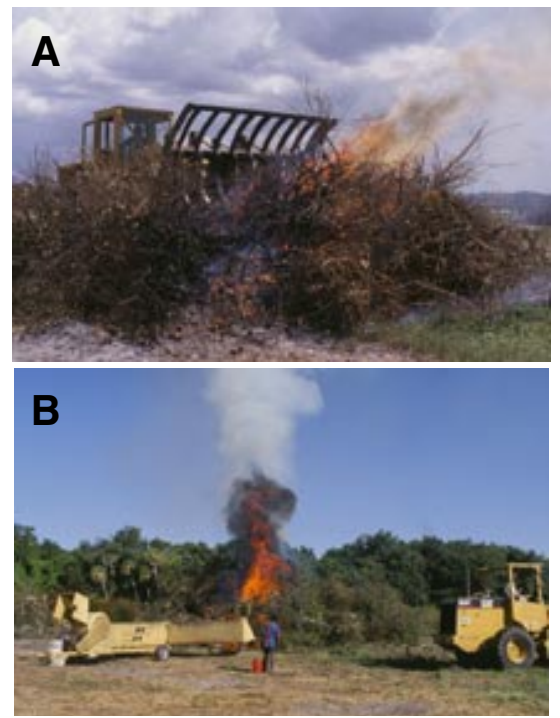

Fig. 14. A, Bulldozer is used to push out and pile up citrus in a commercial grove with citrus canker. Infected and immediately adjacent trees have been previously burned in place to immediately stop the possible dispersal of inoculum. $B$, Exposed and charred, infected citrus is destroyed by burning. 
ones. However uncomfortable and at times seemingly incompatible simultaneous research and eradication efforts might be, scientific studies conducted during the present and previous (1985 to 1994) canker eradication campaigns have had tremendous positive impact on eradication mentality, methods, and efficacy, the benefits of which cannot be ignored. Still, in an era in which so many astonishing scientific discoveries are taking place, the professional plant pathologist must admit to the public that there is still little in the way of effective, practical, and affordable bacterial plant disease control, and certainly no cure for this rather common bacterial plant disease.

\section{Eradication Justification and Economics}

Since the first $\mathrm{CC}$ eradication campaign, it has been the consensus of scientists, citrus industry representatives, and regulatory authorities at both the state and federal levels to address any $\mathrm{CC}$ reintroduction into Florida with a strong consideration for eradication $(58,70,73)$. Conceptually, support for the basic concept of any pest eradication effort is not as strong as it once was in scientific circles because of the historical tendency to underestimate costs and overestimate the benefits (48). This jaundiced view of pest eradication is based mainly upon marginally successful insect eradication efforts. However, $\mathrm{CC}$ has some fundamental features that make it one of the best, and perhaps one of the few remaining candidates for eradication. Among them are: (i) its easily recognizable and distinctive syndrome that permits quick field diagnosis; (ii) its relatively slow natural spread, its lack of an efficient vector; (iii) its restricted host range on a crop of significant cash value; and (iv) the inability of the pathogen to survive for a significant time period apart from its host.

After careful study, what initially may seem to be a rush to judgment in favor of eradication is actually a well-considered plan that takes into account the need to act swiftly to contain a spreading pest. This concern does not override the need to determine cost benefit ratios for the planned actions. In the case of $\mathrm{CC}$, this decision to attempt eradication was not made hastily, nor was it without some minor dissent (8587). Scientists and industry representatives individually and collectively had anticipated the possibility of CC re-establishment in Florida after the successful eradication campaign in the early part of the twentieth century $(8,10)$. The decision to attempt eradication has considered costbenefit calculations $(46,47)$ that clearly indicate this to be the wise choice in the long run if the disease is caught early and action is taken quickly. Cost estimates are difficult if survey, detection, and/or control are delayed for any reason(s) (public re- sistance, legal action, financial limitations). One significant cost estimate, lost revenue to quarantines from other states and countries, defies accurate quantification. The resounding majority opinion in the scientific and citrus production communities supports the efforts to eradicate when the disease is limited in distribution. Decisions guiding the CCEP are made by a number of panels made up of scientists, citrus production experts and grower groups, fresh fruit packers, citrus nursery operators, and ordinary citizens. Subcommittees are assigned specific advisory tasks in such areas as regulatory issues, technical scientific questions, public relations and education efforts, and risk assessment procedures.

\section{Cost Estimates for Disease Management}

Some quick recounting of the latest estimates for managing canker in Florida is appropriate in this discussion $(43,47)$. Although the bulk of the citrus acreage in Florida is devoted to citrus production destined for the processed product market, about 20 to $25 \%$ of the $\$ 8.5$ billion industry is based on fresh fruit sales. Fresh fruit production has the potential for much greater return over processed fruit, but the cosmetic standards are high.

The total cost for an application of a copper compound for protection of new flushes is currently about $\$ 56$ per acre. In some years, a single application might suffice; in others, several may be necessary to maintain fresh fruit appearance standards. Equipment necessary to apply the pesticide in a timely manner (the application window is not wide for $\mathrm{CC}$ ) could require a one-time expense of between $\$ 23,000$ and $\$ 68,000$ per operation if the equipment is not already owned. One spray in the spring for fungal disease control on fresh fruit might overlap with a copper spray for CC, so this cost would be shared. The total cost of windbreaks (establishment, maintenance, and crop loss from competition and shading) would range from $\$ 45$ to $\$ 65$ per acre per year. Even with these measures in place, estimates from studies in South America place fresh fruit crop losses at $\$ 80$ to $\$ 160$ per acre per year for early oranges, $\$ 31$ to $\$ 79$ per acre per year for mid-season oranges, and $\$ 69$ to $\$ 137$ per acre per year for grapefruit where such culture is still attempted. Field inspection costs would be $\$ 30$ per acre per year. Packinghouse inspection of fruit on the line would cost $\$ 31.50$ per acre per year. Decontamination costs industry-wide would be in the range of $\$ 40$ to $\$ 45$ per acre per year.

Florida's citrus acreage for 1997-98 stood at 845,260 with a record production of $304,450,000$ boxes $(1$ box $=90$ pounds of citrus fruit) with an on-tree value of $\$ 974,469,000$ and a total value of over $\$ 1.5$ billion. Florida produces approximately
$80 \%$ of all citrus in the United States. Presently grapefruit in Florida occupies about 120,000 acres. The percentage of grapefruit produced that goes into the fresh fruit market varies year to year from $40 \%$ to almost $60 \%$. Round orange acreage is around 660,000 , with about $5 \%$ of that acreage managed for fresh fruit production. Although a single spray is not likely to be effective in Florida, calculating the expense of one spray, using the midrange figures for all the cost categories, and ignoring equipment procurement costs, total control expenses plus anticipated crop value losses per year for Florida to deal with endemic CC would equal about \$25 million for fresh fruit alone, and slightly more than $\$ 150$ million for the entire citrus crop. This figure does not consider the value of the markets lost due to quarantines.

\section{Eradication Costs to Date}

From 1996 through late 1999, the eradication program up-front costs escalated from about $\$ 10$ million to about $\$ 50$ million per year. In 2000 , the program has broadened to expend $\$ 145$ million in an all-out effort to gain the upper hand against further disease spread. One overlooked benefit of increased surveys for $\mathrm{CC}$ is that the surveyors are also on the lookout for other significant exotic pests and diseases of citrus (citrus greening, citrus variegated chlorosis, Citrus chlorotic dwarf virus, citrus black spot, and lime witches'broom) in an area where international travel and commerce increase the likelihood of introduction of exotic pests and pathogens. An overlooked cost that is frequently mentioned is the overall value of the trees that are being removed. However, in the legal sense, the diseased and exposed trees that have been and will be removed are without value. This is also true in part in the biological sense, since many diseased trees and exposed trees eventually lose both fruit production and aesthetic value, although this takes time. Admittedly, the more resistant citrus cultivars could remain productive and attractive as landscape specimens over time, but these cultivars are relatively uncommon, not very popular, and would serve as inoculum reservoirs if left in place.

\section{Public Opinion and Support of CCEP}

The vast majority of the population in the urban and suburban areas impacted by the CCEP is either supportive or at least tolerant of the eradication actions as determined by polls conducted by faculty at the University of Florida $(2,3)$. Commercial citrus growers in the other CC quarantine sites around the state are generally willing to cooperate fully with the eradication program once they realize the loss in value of the diseased trees and the risk that keeping such trees in place creates for 
neighboring citrus growers. However, even a small percentage of objectors can mount formidable barriers to eradication progress. These barriers take various forms: lobbying legislators and other elected officials; presenting negative publicity in radio talk shows; initiating Internet communication networks to mount protests and discourage public cooperation; limiting access to critical properties; imposing legal impediments in the form of injunctions; and conducting protest actions accompanied by press releases. Antagonism and even threatening behavior have increased as the CCEP began a policy of removing exposed citrus to a radius of $580 \mathrm{~m}(1,900 \mathrm{ft})$ around diseased citrus, and a few instances of armed resistance have been encountered.

The level of public cooperation with the residential eradication effort is roughly estimated to be around $82 \%$ according to a recent survey (3). This segment either willingly complies or at least tolerates the necessary regulatory activities. This percentage holds true for both residential and commercial citrus producers. Between 5 and $10 \%$ will object strongly enough to take initial steps to stop regulatory activity, and about $1 \%$ take continuing active measures to thwart all regulatory activity. In 1999, a random statewide telephone poll of Florida residents conducted by the Agriculture Institute of Florida (2) revealed that half those polled knew that the state's citrus crop was threatened by certain diseases, and of that group, $62 \%$ named CC as one of those diseases. Furthermore, of those who named canker as one of the serious threats to Florida citrus, over $75 \%$ knew that tree destruction was necessary to control the disease, and more than $80 \%$ understood that both commercial and residential trees were being impacted by the disease. These numbers indicate that the general level of knowledge about $\mathrm{CC}$ is relatively high among Florida residents and that regulators have some reason to be optimistic about the public's understanding and acceptance of the reasons for the eradication campaign.

Although CC has been active in the southeastern Florida quarantine area since late 1995, a significant segment of that population seems to know little about the reason for the eradication program. Only $60 \%$ of those polled admitted to some familiarity with the eradication effort. About $30 \%$ knew they had been visited by program personnel. Two-thirds thought they did not live in a quarantine area (although in fact they did), and only one-fifth of the respondents were aware that a toll-free help line was in operation. Still, whether informed or not, the vast majority (about $82 \%$ ) of the population in the urban and suburban areas impacted by the program in Miami-Dade and Broward counties in the southeastern Florida quarantine area are either strongly or somewhat supportive of the eradication actions as determined by a second professional public opinion poll (3).

In some cases, unintentional, uninformed, or perhaps even intentional propagation, movement, and replanting of susceptible citrus in the residential quarantine zone of southeastern Florida has been encountered. Unregistered citrus nurseries have proven to be the source of diseased plants on several occasions. (Florida law requires all plant nurseries to register with the FDACS-DPI.) Some of these nurseries were small and operated by skilled hobbyists for personal use, while others were medium-sized commercial nurseries operating outside the law producing and offering plants for local sale. When found, these illegal nurseries have been shut down. Rules have been changed to prohibit residents from keeping citrus in containers (because of their portability) unless they are a previously established legal nursery and their customers are in a non-citrusproducing state.

The public that is impacted by the CCEP, particularly those outside the realm of commercial citrus production, is slow to recognize that plant diseases are handled differently than animal or human diseases. Plants are rarely treated as individual patients, because the single plant is of limited value and/or the technology does not yet exist to effectively and efficiently treat the individual plant. Furthermore, many of the plants in the residential environment are already in poor general health due to abuse, poor nutrition, and overall neglect. Still, citrus has the ability to produce an acceptable crop to meet homeowner standards under low maintenance circumstances. Gardeners who have experience producing some of their own fruits and vegetables also take a more tolerant viewpoint concerning blemishes on the food they eat. Since the full impact of CC is not realized on a diseased tree for several growing seasons, the hobby citrus grower may question the need for eradication when the disease is intercepted early. It is ironic that citrus receiving the best husbandry by horticultural standards is also the most susceptible to $\mathrm{CC}$ due to regular growth flushes producing an abundance of young tissue.

Also misunderstood is the fact that the inoculum causing CC is currently impossible to detect using practical methods apart from the expression of symptoms on diseased plants. By the time the disease manifests, inoculum has already jumped ahead of the detection surveys to some variable distance dependent on recent weather events and human activity. The etiology of $\mathrm{CC}$ necessitates destruction of exposed plants if eradication is ever to be achieved. Previous legal decisions that have gone as high as the Florida State Supreme Court level have always upheld the authority of the FDACS-DPI to destroy CC-infected and exposed trees within $38 \mathrm{~m}(125 \mathrm{ft})$ without compensation. Diseased and exposed citrus is deemed a public nuisance and therefore subject to lawful seizure. In June 2000, the governor of Florida signed into law more explicit legislation that clearly authorizes the state to take all exposed citrus within the $580-\mathrm{m}(1,900-\mathrm{ft})$ exposure radius. The law also makes clear the illegality of knowingly harboring citrus infected with $\mathrm{CC}$ on private property.

\section{Public Education and Effective Plant Health Regulations}

The CCEP has gradually adopted more progressive and constructive approaches to educate the public about the goals and objectives of the eradication program. A well-informed populace is also better prepared to accept the more onerous aspects of the eradication program. Newspaper advertisements, spot radio ads, mass mailouts in target areas, telephone help lines, billboards along major trafficways, doorhangers, handbills, citizen's committee meetings, interviews with local politicians, neighborhood association meetings, and an Internet web page have all been utilized, especially in the residential quarantine areas in South Florida.

Plant regulatory agencies at the state (FDACS-DPI) and federal (USDA-APHISPPQ) level are not designed for and are ill equipped to act as law enforcement agencies. The success of regulatory programs depends heavily upon the voluntary compliance and cooperation of the regulated parties, although fines may be levied to encourage compliance. Far more effective than fines or other penalties is an informed populace that understands the wisdom of compliance from a personal and community perspective, and submits to the regulations even when the outcome is personally not very pleasant. Credibility of the source of that information is a legitimate concern of the affected parties. Pushing too hard to exercise legitimate regulatory authority only drives illegal activities underground and encourages deliberate subterfuge of program goals. It can also erode the base of political support as public sentiment against the seemingly harsh methods of the program grows. When public support diminishes to a certain critical mass, funding dries up, and the program is stopped without reaching its goal.

A recent study by Brunk (4) offers some conceptual insight into implementing public policy by improving this delicate process of integrating risk assessment into risk management and communication. The tendency for regulatory scientists is to regard the whole of their work as valueneutral, nonarbitrary, and nonpolitical. This is a fallacy. Integration of perspectives other than the scientific (i.e., legal, logistical, financial, public relations, political, and ethical) must be considered in their proper places and times. Brunk identifies the entire risk analysis process as having three steps: (i) risk assessment (this is purely scientific); (ii) risk management 
(involving the social sciences); and finally (iii) risk communication (a political science exercise). Even then, the logistics of carrying out the decisions made by this process, keeping records, and managing workforces must be integrated, involving still more specialized disciplines.

One favorable development in the public relations arena has been a USDA/FDACSsponsored program to replace the tree canopy lost to CC with other suitable fruit or shade trees. The tree replacement program is not meant to be direct compensation for citrus trees lost to CC (diseased and exposed trees legally have no economic value), but is intended to restore the lost tree canopy for environmental and aesthetic reasons. Under the present policy, each residential property owner that loses any citrus trees in the eradication effort is issued a debit card with a $\$ 100$ limit to purchase various plant materials other than citrus to restore the canopy on that property.

On the commercial front, a crop insurance program overseen by the USDA Federal Crop Insurance Corporation has been expanded starting in 2000 to help defray both the crop and plant losses that citrus growers may experience as a result of CC eradication. Final details of any coverage for commercial losses due to the eradication effort have yet to be finalized. Serious plans to offer insurance coverage for citrus nursery losses due to $\mathrm{CC}$ infection on the premises are also in progress at the federal level. Certainly, such an insurance reimbursement for those who choose to enroll in such a plan could be expected to engender broader support for the eradication effort.

\section{Cultural Aspects \\ of Public Relations}

In the Miami area and much of the rest of South Florida, the population is predominantly Spanish speaking, so it has been necessary to have translators available for much of the door-to-door visitation and other forms of communication. This language barrier, along with the concomitant cultural differences, was a significant source of distrust of early program personnel by the local population. As the program has matured, much of the workforce is now made up of employees who can more easily win the trust of those impacted by the program because they speak Spanish as a native language and understand issues of concern to local residents. Since repeated visits to each property are necessary, efforts have been made to have the same survey crews visit each time if possible in the hope that familiarity will foster better relations.

A good number of those impacted by the CCEP in the southeastern Florida quarantine area are elderly retirees. Citrus production in their yards is an important and fulfilling activity for them, and loss of their trees to $\mathrm{CC}$ is especially distressing. The pain is heightened when they consider that they will probably not live long enough to ever be able to grow their own citrus at home again. Even with some financial allowance for canopy replacement, the elderly are not able to watch new plants grow to a size that replaces those citrus trees lost. Similarly, citrus trees that have been planted to memorialize a loved one or mark the birth of a child stir up similar feelings. Some residents in the area have gone so far as to allege that the CCEP is a conspiracy hatched by the regulatory agencies and commercial citrus producers to force residents to purchase citrus rather than grow their own. Several residents originally from Cuba have described the nationalization of personal property with the communist takeover of their country in $1959-60$ by Fidel Castro. Today, any government seizure of their private property evokes vivid reminders of that event.

\section{What Does the Future Hold?}

It is extremely important that the current progress of the CCEP continue unimpeded, if not further facilitated, on all fronts if eradication is to be achieved. Recent implementation of an Incident Command System style of management (49) for the residential southeastern Florida component of the CCEP and the allotment of ample funds to buy vehicles, hire enough surveyors, and contract tree removal crews have resulted in major advancements. Identification and removal of diseased and exposed trees in the southeastern Florida quarantine area and vicinity is greatly facilitated (24). This is considered by many to be the last opportunity to succeed in eradicating CC from Florida. The point at which an eradication program evolves into a containment program may seem important in principle, but logistically and tactically there would be no difference. Funding for an effective and finite eradication program is more likely to materialize than funding for a permanent containment program. Even though there has been some citizen opposition to the best eradication efforts politically acceptable and affordable, an honest assessment of these eradication efforts reveals that they have been only marginally successful in limiting the disease so far in the most heavily infested residential areas. Therefore, any relaxation in tactics with a conceptual shift from eradication to containment would not be advisable or warranted.

Several lessons have been learned, or more accurately reinforced, in the course of this campaign so far. Certainly, the ecological threat from invasive species, recently acknowledged at the federal level in the form of the Invasive Species Initiative (7), is not going to lessen. One glaring need that continues to haunt exotic pest and disease management efforts is the need to start with an adequate and versatile funding base that reflects the value of what is at stake in such biological-ecological struggles. Sufficient funds available at the outset to address the Miami CC infestation would likely have made for a much different situation today. However, money alone is not enough. Political resolve at all levels of government to make unpopular but scientifically and economically sound decisions must be bolstered by proactive, fulltime public relations efforts and wholehearted industry support and participation. These could inform the populace about exotic pest and disease risks and their personal responsibility in such matters. This sort of public relations effort would help improve the overall level of understanding and cooperation between rural-agricultural and urban sectors of society. Furthermore, it would help private citizens understand the inherent risks and privileges of growing citrus as a hobby or a landscape plant in a state whose economy depends heavily on that crop.

Florida's citrus growers have an increasingly rare advantage over other citrus production areas around the world to produce top quality fresh fruit in an environment free of the biological and marketing restrictions of $\mathrm{CC}$. The value over time of this advantage is difficult to quantify. Also difficult to predict is the likelihood of reintroduction. Reintroduction of $\mathrm{CC}$ would almost certainly be the result of illegal importation of citrus in one form or another, because the unassisted natural spread of inoculum into the peninsula of Florida is inconceivable.

Support for the CCEP is generally strong from the commercial citrus growers. Objectors to the program from the residential camp claim the entire operation lacks a credible scientific foundation. Meanwhile, program representatives, simply trying to discharge their duties to the best of their abilities, struggle with ways to convey what they consider to be sound biological information in a manner that the layperson can understand. At least two factors work against this. First, the residential citrus grower impacted by the CCEP lacks the time and perhaps the motivation to deal with this complex issue among all the other private and public concerns competing for their attention. Secondly, the traditional intuitive negative reaction to "government help" has considerable inertia and popular appeal. Where objectors portray the program as an act of a totalitarian government, proponents of the program, bolstered by opinion polls, see it more in terms of a minority preventing the proper exercise of self government. In the final analysis, even a biologically and economically sound approach to eradication that touches off a political firestorm will doom a project as easily as poor scientific judgment, technical incompetency, or logistical bungling.

A second lesson: Although it borders on the inevitable in this litigious society that 
even mildly controversial public programs can end up in the courts, this forum should be perceived from the outset as the next best place to resolve the complex biological questions behind the programs. In some respects, a decision must be made on how much investment in public relations is warranted, versus how much might be required for legal defense. A well-run public information campaign that provides the level of popular and political support required for a successful program facilitates a more favorable outcome in the event of litigation. Certainly, every aspect of the eradication program must strive for consistently high standards, or the project will falter as legal actions commence. The expense of litigation is further incentive to find a better way. Therefore, serious investment in public education should be built into any regulatory agency's budget, both for routine and emergency program support.

A final lesson inherent in dealing with an organism that is the target of eradication: it is extremely difficult to conduct research on the target organism while simultaneously trying to eradicate it. The need to base regulatory actions on the most recent authoritative information in the particular locale is counterbalanced by the necessity of swift action to contain the pest or pathogen. Legitimate research pursuits, such as testing the feasibility of composting diseased plant wastes or fine-tuning sanitation practices, are extremely challenging due to regulatory constraints. Only a disheartening runaway disease outbreak that can be expected to persist for some time in the middle of the quarantine area can provide a short window of opportunity for quick epidemiological research projects. This study has elucidated the previously underestimated spread potential of CC coupled with the advent of the citrus leaf miner (24). Laboratory research projects must be conducted under strict biological containment that is not widely available, nor is it cheap to obtain. Moreover, many persons come forward with various unproven schemes and products they are certain will be the "magic bullet" in the battle against the disease. Dealing effectively with these schemes and proposals is a public relations and political tightrope, very time-consuming, and ultimately not very productive.

One fundamental question in regulatory plant pathology is beginning to receive some additional scrutiny: should the disease, the pathogen, or the actual pathogenicity genes be the object of regulatory action? The continuing discoveries of genetically distinct but related strains of $\mathrm{CC}$ bacteria (B-strain, C-strain, citrus bacterial spot, and the key/Mexican lime specific strains) offer hints that the CC disease or canker-like diseases can be caused by more than one pathogen. Recent genetic discoveries in the xanthomonads that cause leaf spots on Solanaceae suggest that quite different microorganisms can cause essentially the same disease on those hosts (37). Variability in the Erwinia species that cause fire blight and closely related diseases in the Rosaceae (39) and the different species of Alternaria that cause essentially identical leaf and fruit spots in citrus $(52,65,66)$ are additional examples. How easily do new strains of these pathogens arise? Should new strains or pathogens ever be the target of regulatory action (as was attempted with citrus bacterial spot)? Is the likelihood of new strain development a legitimate criterion for regulatory decision-making? Should regulatory action be reserved for the specific gene sequences that result in significant economic impact? How stringent must the diagnostic standards be for regulatory action? How can the full impact of a pathogen be appreciated unless some unfortunate community suffers the level of damage that might inspire and justify regulatory action? And can the extrapolation of disease impact from one environment or location to another be accurate enough to use as a basis for starting or rejecting regulatory action?

At the very least, regulations must be carefully written from a legal perspective to accurately define specifically what is and what is not regulated. Clear and concise regulations become even more imperative as phytopathologists discover more about the genetic basis of pathogenicity. Since economic impact from the plant disease is historically the basis of any regulatory action, a strong case can be made for making the disease syndrome itself the target.

Should the eradication program fail, the citrus industry in Florida will certainly survive, but in a drastically modified and less profitable form. No doubt the more susceptible cultivars of citrus (grapefruit, navel orange, and pineapple sweet orange among them) sooner or later would be nearly eliminated from production except under very protected conditions. The opportunity to successfully grow susceptible citrus without a continuing struggle in the residential setting would vanish. Lucrative domestic and foreign markets for fresh Florida grapefruit, a crop for which Florida's climate is especially well suited, would be the first to suffer. The industry would likely move toward a more processed product orientation rather than fresh fruit product, unless some easing of sanctions against exporting fresh fruit from canker-endemic areas occurs. This trend toward processed over fresh fruit has evolved in South America in areas where the disease has become endemic. In the short run, production costs in Florida would rise to cover the expense of establishing and maintaining windbreaks in the remaining citrus orchards, applying additional copper to protect the new flushes from infection, decontaminating personnel and equipment, and inspecting at appropriate stages to minimize disease incidence (43). Such cost increases are inevitably passed on to the consumer, assuming the rise in price does not erode product demand. In the long run, marketing of fresh citrus juice or fresh fruit with the peel mechanically or enzymatically removed (a situation in which lesions won't matter) may be emphasized and perfected, but the more susceptible cultivars may still need some level of $\mathrm{CC}$ protection using windbreaks and pesticides to allow fruit to remain on the tree until ripe. Another promising development lies in the arena of genetically engineered CC-resistant citrus. Recent controversies surrounding this modern technological approach to solving the $\mathrm{CC}$ disease problem in Florida may render this a somewhat hollow victory unless consumer acceptance of genetically engineered food crops increases. Succeed or fail, several important lessons will have been learned from this most recent experience of CC in Florida, the most important being that even though the concept of pest eradication is perhaps outdated in many instances, it is still a wise approach from the biological and economic perspectives to the $\mathrm{CC}$ problem in Florida.

\section{Acknowledgments}

We thank the many people of the joint statefederal Citrus Canker Eradication Program in Florida for their assistance in preparing this manuscript. Particular thanks go to Deputy Commissioner of Agriculture Craig Meyer, FDACS-DPI Division Director Richard Gaskalla, and Assistant Director Connie Riherd for their able leadership and support, and to John Saddler and Aaron Reecher for preparing the maps.

\section{Literature Cited}

1. Bergamin-Filho, A., Amorim, L., Laranjeira, F., and Gottwald, T. R. 2000. Epidemiology of citrus canker in Brazil with and without the Asian citrus leaf miner. (Abstr.) Proc. Int. Citrus Canker Res. Workshop, June 20-22, 2000. Florida Department of Agriculture and Consumer Services. Published on-line.

2. Breeze, M. 1999. 1999 Ag consumer survey by the Agriculture Institute of Florida. Section III, Citrus canker. Citrus Veg. Mag. 64:35-36

3. Breeze, M. H. 2000. Public knowledge and opinion of residents of Dade and Broward Counties, Florida regarding citrus canker and the citrus canker eradication program of the Florida Department of Agriculture and Consumer Services. June, 2000. University of Florida, Institute of Food and Agricultural Sciences, Gainesville.

4. Brunk, C. G. 1999. Principles and practice of risk management. N. Am. Plant Prot. Organ. Annu. Rep., 1998-99. pp. 1-7.

5. Canteros, B. I. 2000. Citrus canker in Argentina - Control, eradication and current management. (Abstr.) Proc. Int. Citrus Canker Res. Workshop, June 20-22, 2000. Florida Department of Agriculture and Consumer Services. Published on-line.

6. Civerolo, E. L. 1984. Bacterial canker disease of citrus. J. Rio Grande Valley Hortic. Assoc. 37:127-146.

7. Clinton, W. J. 1999. Presidential Executive Order 13112 on invasive species (EOIS), 6183 Federal Register 24: 25, February 8. 


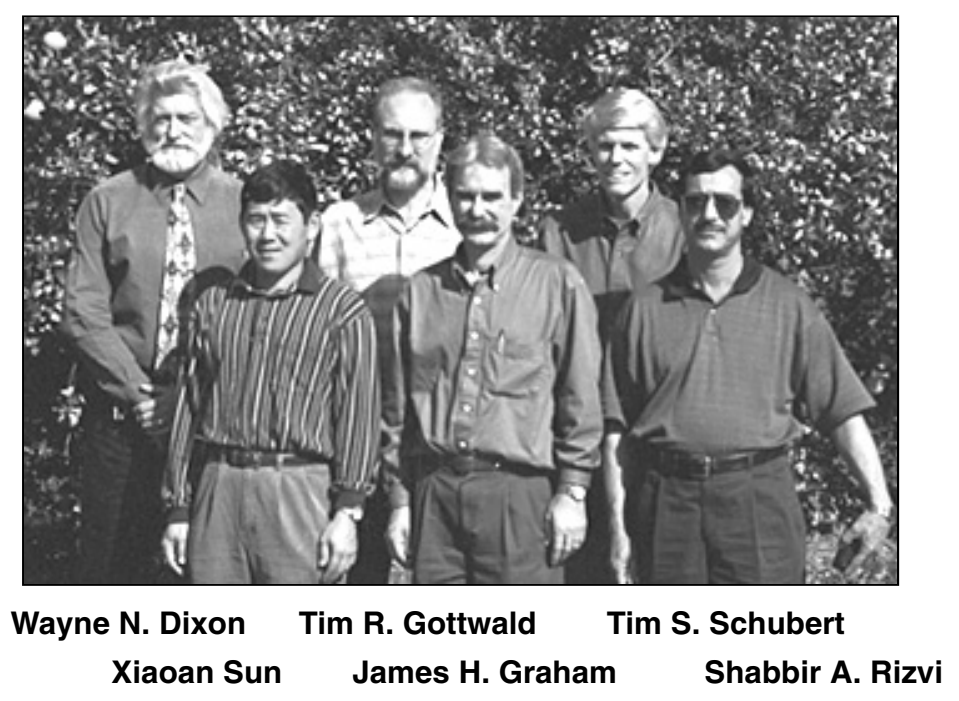

Dr. Schubert is the administrator for the plant pathology section of the Florida Department of Agriculture and Consumer Services-Division of Plant Industry, where he has worked on various aspects of diagnostic and regulatory plant pathology for over 20 years. He oversees the operations of the FDACS-DPI Plant Disease Clinic and the Plant Disease Quarantine Facility. Dr. Schubert received his Ph.D. in plant pathology in 1982 from the University of Missouri-Columbia, where he assisted in the Extension Plant Disease Clinic while studying the ultrastructure of vesicular-arbuscular mycorrhizas. He has recently served as president of the Florida Phytopathological Society and on the Regulatory, Plant Disease Diagnosis, and Environmental Quality and Plant Health Committees with the American Phytopathological Society. He specializes in the diagnosis of fungal and abiotic diseases and plant problems of complex etiology.

Dr. Rizvi is employed by the Florida Department of Agriculture and Consumer Services-Division of Plant Industry as chief plant pathologist for the Citrus Canker Eradication Program, working in south Florida's canker program since January 1997. He received his Ph.D. from South Dakota State University in 1990, where he worked on leaf rust of wheat. He has published on several postdoctoral research projects at lowa State University and South Dakota State University involving chloride interactions with wheat leaf rust, foliar diseases of alfalfa, seedling diseases of soybean, and foliar diseases of wheat. He is registered as a Certified Professional Plant Pathologist with the American Phytopathological Society. He specializes in genetics of host-pathogen interactions, epidemiology, and plant disease management using host resistance.

Dr. Sun is a plant pathologist with the Florida Department of Agriculture and Consumer Services-Division of Plant Industry. He received a B.A. in plant protection in 1982 at Fujian Agricultural University, China, an M.S. in mycology in 1988 at Zhejiang Agricultural University, China, and a Ph.D. in plant pathology in 1996 at the Louisiana State University. $\mathrm{He}$ was a research scientist at the Fujian Academy of Agricultural Sciences before he moved to the United States to pursue his professional career in plant pathology. His research and professional activities include evaluation of resistant cultivars against Asiatic citrus canker and rice blast, taxonomy of plant pathogenic imperfect fungi, and biological control of soilborne fungal plant and forest diseases using antagonistic fungi or bacteria. He joined the FDACS in 1996 and has been involved in diagnosis of bacterial plant diseases, especially citrus canker field and laboratory diagnosis, and citrus canker epidemiology in urban Miami.

Dr. Gottwald is a plant pathologist and the research leader for subtropical plant pathology at the USDA, Agricultural Research Service, U.S. Horticultural Research Laboratory in Ft. Pierce, FL. He joined ARS in 1979. He received a B.S. in botany from California State University at Long Beach in 1975 and a Ph.D. in

plant pathology from Oregon State University in 1979. Previously, he was stationed at the USDA, ARS, Fruit and Tree Nut Research Laboratory in Byron, GA, where he worked on pecan diseases. His main research thrusts have been to examine the epidemiology, etiology, survey methods, detection, control, and host-parasite interactions of domestic and exotic diseases of citrus, including Asiatic citrus canker, citrus bacterial spot, tristeza, Huanglungbing, citrus variegated chlorosis, greasy spot, scab, and blight and other invasive plant pathogens such as Plum pox virus in an attempt to develop disease control strategies and aid regulatory agencies who deal with invasive pathogens. He has established a number of cooperative international research programs in Argentina, Brazil, China, Costa Rica, Dominican Republic, France, Philippines, Spain, and Taiwan. Dr. Gottwald has also served the American Phytopathological Society as associate editor for Phytopathology, as member and chair of several committees, senior editor for APS Press, was awarded the APS Lee M. Hutchins Award in 1994, and became a Fellow of APS in 1999.

Dr. Graham is professor of soil microbiology at the University of Florida, Citrus Research and Education Center at Lake Alfred. He received his Ph.D. degree in mycology from Oregon State University in 1980. Since joining the University of Florida in 1981, his research has focused primarily on issues relating to citrus root health, including the epidemiology and management of Phytophthora spp. and the pathogens' interactions with root-feeding pests, and the biology of arbuscular mycorrhizas. In the 1980s, he conducted collaborative studies with Dr. Gottwald, USDA-ARS, on the etiology, epidemiology, and host range of Xanthomonas axonopodis pv. citrumelo, the cause of citrus bacterial spot. They demonstrated that this leaf-spotting disease of nursery trees is not a form of citrus canker and does not cause crop loss in orchards. He is currently the coordinator of the Institute of Food and Agricultural Sciences quarantine greenhouse-field research program on citrus canker, again in collaboration with Dr. Gottwald.

Dr. Dixon is the bureau chief of entomology, nematology, and plant pathology in the Florida Department of Agriculture and Consumer Services (FDACS). He received his Ph.D. in forestry from the University of Maine. He was the forest entomologist for FDACS from 1980 to 1992 and was appointed to his current position in 1993. His primary responsibility is identification or diagnosis of exotic plant pests newly introduced into Florida. His research experience includes pest life tables; spatial and temporal population dynamics; pheromone trapping; sampling methodology; control and eradication strategies in pine seed orchards, commercial forest lands, urban landscape, and commercial citrus groves; and biological control. Of late, considerable effort has gone into the risk assessment of Asiatic citrus canker found in residential door yards and commercial citrus groves in Florida and the development of regulatory strategies for anticipated exotic agricultural pests. 
8. Cohen, M. 1980. Citrus canker (Xanthomonas citri) in the major production area of Brazil. Fla. Grower Rancher 73:22-23.

9. Cook, A. A. 1988. Association of citrus canker pustules with leaf miner tunnels in North Yemen. Plant Dis. 72:546.

10. Crandall, M. A. 1978. There's an enemy lurking at the door (Citrus canker, Xanthomonas citri). Fla. Grower Rancher 71:12, 14.

11. Danos, E., Berger, R. D., and Stall, R. E. 1984. Temporal and spatial spread of citrus canker within groves. Phytopathology 74:904-908.

12. Danos, E., Bonazzola, R., Berger, R. D., Stall, R. E., and Miller, J. W. 1982. Progress of citrus canker on some species and combinations in Argentina. Proc. Fla. State Hortic. Soc. 94:15-18.

13. Dixon, W. N., Schubert, T. S., Sun, X., Gottwald, T. R., Graham, J. H., Hebb, L., Poe, S. R., and Hornyak, M. 2000. Risk assessment. (Abstr.) Proc. Int. Citrus Canker Res. Workshop, June 20-22, 2000. Florida Department of Agriculture and Consumer Services. Published on-line.

14. Dopson, R. N. 1964. The eradication of citrus canker. Plant Dis. Rep. 48:30-31.

15. Ferguson, J., Schubert, T., and Miller, J. 1984. Citrus Canker. University of Florida, Agricultural Extension Service, Gainesville. Fruit Crops Fact Sheet. 4 p.

16. Gabriel, D. W., Kingsley, M. T., Hunter, J. E., and Gottwald, T. R. 1989. Reinstatement of Xanthomonas citri (ex Hasse) and X. phaseoli (ex Smith) to species and reclassification of all $X$. campestris pv. citri strains. Int. J. Systematic Bacteriol. 39:14-22.

17. Goto, M., and Hyodo, H. 1985. Role of extracellular polysaccharides of Xanthomonas campestris pv. citri in the early stage of infection. Ann. Phytopathol. Soc. Jpn. 51:2231.

18. Goto, M., Ohta, K., and Okabe, N. 1975. Studies on saprophytic survival of Xanthomonas citri (Hasse) Dowson. 1. Detection of the bacterium from a grass (Zoysia japonica). Ann. Phytopathol. Soc. Jpn. 41:9-14.

19. Goto, M., and Yaguchi, Y. 1979. Relationship between defoliation and disease severity in citrus canker [Xanthomonas citri]. Ann. Phytopathol. Soc. Jpn. 45:689-694.

20. Gottwald, T. R., and Graham, J. H. 1992. A device for precise and nondisruptive stomatal inoculation of leaf tissue with bacterial pathogens. Phytopathology 82:930-935.

21. Gottwald, T. R., Graham, J. H., and Egel, D. S. 1992. Analysis of foci of Asiatic citrus canker in a Florida citrus orchard. Plant Dis. 76:389-396.

22. Gottwald, T. R., Graham, J. H., and Schubert, T. S. 1997. An epidemiological analysis of the spread of citrus canker in urban Miami, Florida, and synergistic interaction with the Asian citrus leafminer. Fruits 52:371-378.

23. Gottwald, T. R., Graham, J. H., and Schubert, T. S. 1997. Citrus canker in urban Miami: An analysis of spread and prognosis for the future. Citrus Ind. 78:72-78.

24. Gottwald, T. R., Hughes, G., Graham, J. H., Sun, X., and Riley, T. 2001. The citrus canker epidemic in Florida: The scientific basis of regulatory eradication policy for an invasive species. Phytopathology 91:30-34.

25. Gottwald, T. R., McGuire, R. G., and Garran, S. 1988. Asiatic citrus canker: Spatial and temporal spread in simulated new planting situations in Argentina. Phytopathology 78:739-745.

26. Gottwald, T. R., Reynolds, K. M., Campbell, C. L., and Timmer, L. W. 1992. Spatial and spatiotemporal autocorrelation analysis of citrus canker epidemics in citrus nurseries and groves in Argentina. Phytopathology 82:843-
851

27. Gottwald, T. R., Sun, X., Riley, T., Graham, J., and Hughes, G. 2000. Estimating spread of citrus canker in urban Miami via differential GPS. (Abstr.) Proc. Int. Citrus Canker Res. Workshop, June 20-22, 2000. Florida Department of Agriculture and Consumer Services. Published on-line.

28. Gottwald, T. R., and Timmer, L. W. 1995. The efficacy of windbreaks in reducing the spread of citrus canker caused by Xanthomonas campestris pv. citri. Trop. Agric. 72:194-201.

29. Gottwald, T. R., Timmer, L. W., and McGuire, R. G. 1989. Analysis of disease progress of citrus canker in nurseries in Argentina. Phytopathology 79:1276-1283.

30. Graham, J. H., and Gottwald, T. R. 1990. Variation in aggressiveness of Xanthomonas campestris pv. citrumelo associated with citrus bacterial spot in Florida citrus nurseries. Phytopathology 80:190-196.

31. Graham, J. H., and Gottwald, T. R. 1991. Research perspectives on eradication of citrus bacterial diseases in Florida. Plant Dis. 75:1193-1200.

32. Graham, J. H., Gottwald, T. R., Civerolo, E. L., and McGuire, R. G. 1989. Population dynamics and survival of Xanthomonas campestris in soil in citrus nurseries in Maryland and Argentina. Plant Dis. 73:423-427.

33. Graham, J. H., Gottwald, T. R., Riley, T. D., and Achor, D. 1992. Penetration through leaf stomata and growth of strains of Xanthomonas campestris in citrus cultivars varying in susceptibility to bacterial diseases. Phytopathology 82:1319-1325.

34. Graham, J. H., Gottwald, T. R., Riley, T. D., and Bruce, M. A. 1992. Susceptibility of citrus fruit to bacterial spot and citrus canker. Phytopathology 82:452-457.

35. Graham, J. H., Gottwald, T. R., Riley, T. D., Cubero, J., and Drouillard, D. L. 2000. Survival of Xanthomonas campestri pv. citri $(X c c)$ on various surfaces and chemical control of Asiatic citrus canker (ACC). (Abstr.) Proc. Int. Citrus Canker Res. Workshop, June 20-22, 2000. Florida Department of Agriculture and Consumer Services. Published online.

36. Heppner, J. P. 1993. Citrus leafminer, Phyllocnistis citrella, in Florida. Trop. Lepidoptera 4:49-64.

37. Jones, J. B., Bouzar, H., Stall, R. E., Almira, E. C., Roberts, P. D., Bowen, B. W., Sudberry, J., Strickler, P. M., and Chun, J. 2000. Systematic analysis of xanthomonads (Xanthomonas spp.) associated with tomato and pepper lesions. Int. J. Systematic Evolutionary Microbiol. 50:1211-1219.

38. Kalita, P., Bora, L. C., and Bhagabati, K. N. 1997. Goat weed - A host of citrus canker (Xanthomonas campestris pv. citri). J. Mycol. Plant Pathol. 27:96-97.

39. Kim, W. S., Gardan, L., Rhim, S. L., and Geider, K. 1999. Erwinia pyrifoliae sp. nov., a novel pathogen that affects Asian pear trees (Pyrus pyrifolia Nakai). Int. J. Systematic Bacteriol. 49:899-906.

40. Koizumi, M. 1985. Citrus canker: The world situation. Pages 2-7 in: Citrus Canker: An International Perspective. L. W. Timmer, ed. University of Florida, Lake Alfred.

41. Koizumi, M., and Grierson, W. 1979. Relation of temperature to the development of citrus canker lesions in the spring. Proc. Int. Soc. Citricult. 3:924-928.

42. Leite, R. P., Jr. 1990. Citrus canker. Prevention and control in the state of Parana. Fundacao IAPAR, Circular Instituto Agronomico do Parana, 61.

43. Leite, R. P., Jr., Mohan, S. K., Pereira, A. L. G., and Campacci, C. A. 1987. Integrated control of citrus canker - Effect of genetic re- sistance and application of bactericides. Fitopatol.-Bras. 12:257-263.

44. Loucks, K. W. 1934. Citrus Canker and its Eradication in Florida. Archives of the Florida Department of Agriculture - Division of Plant Industry, Gainesville.

45. Medina-Urrutia, V. M., and Stapleton, J. J. 1986. Control of mexican lime bacteriosis with copper-based products. Proc. Fla. State Hortic. Soc. 98:22-25.

46. Muraro, R. P. 1986. Observations of Argentina's citrus industry and citrus canker control with estimations of additional costs to Florida citrus growers under a Florida citrus canker control program. Food and Resource Economics Department - Institute of Food and Agricultural Sciences, University of Florida. Staff Pap. 289

47. Muraro, R. P., Roka, F., and Spreen, T. H 2000. An overview of Argentina's citrus canker control program with applicable costs for a similar program in Florida. (Abstr.) Proc Int. Citrus Canker Res. Workshop, June 2022, 2000. Florida Department of Agriculture and Consumer Services. Published on-line.

48. Myers, J. H., Savoie, A., and van Randen, E. 1998. Eradication and Pest Management. Annu. Rev. Entomol. 43:471-491.

49. National Wildfire Coordinating Group. 1994. Incident Command System National Training Curriculum NFES 2439. National Interagency Fire Center, Boise, ID.

50. Palazzo, D. A., Malavolta, V. A., Jr., and Nogueira, E. M. de C. 1984. Effect of some climatic factors on the index of infection of citrus canker caused by Xanthomonas campestris pv. citri on Valencia orange (Citrus sinensis), in Bataguassu, M.S. Fitopatol. Bras. 9:283-290.

51. Palm, M. E., and Civerolo, E. L. 1994. Isolation, pathogenicity, and partial host range of Alternaria limicola, causal agent of mancha foliar de los citricos in Mexico. Plant Dis. 78:879-883.

52. Peever, T. L., Canihos, Y., Olsen, L., Ibañez, A., Liu, Y.-C., and Timmer, L. W. 1999. Population genetic structure and host specificity of Alternaria spp. causing brown spo of Minneola tangelo and rough lemon in Florida. Phytopathology 89:851-860.

53. Pereira, A. L., Watanabe, K., Zagato, A. G., and Cianciulli, P. L. 1976. Survival of Xan thomonas citri (Hasse) Dowson [the causal agent of citrus canker] on sourgrass (Trichachne insularis (L.) Nees) from eradicated orchards in the State of Sao Paulo, Brazil. Biologico 42:217-221.

54. Pereira, A. L., Watanabe, K., Zagatto, A. G., and Cianciulli, P. L. 1978. Survival of Xanthomonas citri (Hasse) Dowson, the causal agent of "citrus canker" in the rhizosphere of guineagrass (Panicum maximum Jacq.). Biologico 44:135-138.

55. Rhoades, A. S., and DeBusk, E. F. 1931 Diseases of Citrus in Florida. University of Florida Agric. Exp. Stn. Bull. 229.

56. Rodrigues, J. C. V., Rossetti, V., Machado, M A., Sobrinho, J. T., and de Lima-Nogueira, N. 1998. Citrus leaf miner: A factor for increase of pests and citrus canker. Laranja 19:49-60.

57. Schaad, N. W., Vidaver, A. K., Lacy, C. Y., Rudolph, K., and Jones, J. B. 2000. Evaluation of proposed amended names of several pseudomonads and xanthomonads and recommendations. Phytopathology 90:208-213.

58. Schoulties, C. L., Civerolo, E. L., Miller, J. W., Stall, R. E., Krass, C. J., Poe, S. R., and Ducharme, E. P. 1987. Citrus canker in Florida. Plant Dis. 71:388-395.

59. Schoulties, C. L., Miller, J. W., Stall, R. E., Civerolo, E. L., and Sasser, M. 1985. A new outbreak of citrus canker in Florida. Plant Dis. 69:361. 
60. Schubert, T. S. 1991. Recent history of the citrus canker eradication programs in Florida. Newsl. Fla. Phytopathol. Soc. 2:1-6.

61. Schubert, T. S., Graham, J. H., and Timmer, L. W. 2000. Citrus Canker. 2000 Florida Pest Management Guide. J. L. Knapp, ed. Institute of Food and Agricultural Sciences, Florida Cooperative Extension Service, University of Florida, Gainesville. p. 30.1.1-8.

62. Schubert, T. S., and Miller, J. W. 2000. Bacterial citrus canker. Fla. Dep. Agric. Conservation Serv. - Div. Plant Ind. Plant Pathol. Circ. 377, revised.

63. Schubert, T. S., Miller, J. W., and Gabriel, D. W. 1996. Another outbreak of bacterial canker on citrus in Florida. Plant Dis. 80:1208.

64. Serizawa, S., and Inoue, K. 1974. Studies on citrus canker, Xanthomonas citri. III. The influence of wind on the infection of citrus canker. Bull. Shizuoka Prefect. Citrus Exp. Stn. Komagoe Shimizu City, Japan 11:54-67.

65. Simmons, E. G. 1990. Alternaria themes and variations (27-53). Mycotaxon 37:79-119.

66. Simmons, E. G. 1999. Alternaria themes and variations (226-235). Classification of citrus pathogens. Mycotaxon 70:263-323.

67. Sinha, M. K., Batra, R. C., and Uppal, D. K. 1972. Role of citrus leaf-miner (Phyllocnistis citrella Staintan (sic) on the prevalence and severity of citrus canker [Xanthomonas citri (Hasse) Dowson]. Madras Agric. J. 59:240245.

68. Sohi, G. S., and Sandhu, M. S. 1968. Relationship between citrus leafminer (Phyllocnistis citrella Stainton) injury and citrus canker [(Xanthomonas citri (Hasse) Dowson] incidence on citrus leaves. J. Res. Punjab Agric. Univ. (Ludhiana) 5:66-69.

69. Stall, R. E., and Civerolo, E. L. 1991. Research relating to the recent outbreak of citrus canker in Florida. Annu. Rev. Phytopathol. 29:399-420.

70. Stall, R. E., Civerolo, E. L., Ducharme, E. P.,
Krass, C. J., Poe, S. R., Miller, J. W., and Schoulties, C. L. 1987. Management of citrus canker by eradication of Xanthomonas campestris pv. citri. Pages 900-905 in: Plant Pathogenic Bacteria, Current Plant Science and Biotechnology in Agriculture. E. L. Civerolo, A. Collmer, R. E. Davis, and A. G. Gillaspie, eds. Martinus Nijhoff Publishers, Dordrecht, The Netherlands.

71. Stall, R. E., Marcó, G. M., and Canteros de Echenique, B. I. 1982. Importance of mesophyll in mature-leaf resistance to cancrosis of citrus. Phytopathology 72:1097-1100

72. Stall, R. E., Miller, J. W., Marco, G. M., and Canteros de Echenique, B. I. 1980. Population dynamics of Xanthomonas citri causing cancrosis of citrus in Argentina. Proc. Fla. Hortic. Soc. 93:10-14.

73. Stall, R. E., and Seymour, C. P. 1983. Canker, a threat to citrus in the Gulf-Coast states. Plant Dis. 67:581-585.

74. Stapleton, J. J., and Garza-Lopez, J. G. 1988. Epidemiology of a citrus leaf-spot disease in Colima, Mexico. Phytopathology 78:440-443.

75. Sun, M. 1984. The mystery of Florida's citrus canker. Science 226:322-323.

76. Sun, X., Stall, R. E., Cubero, J., Gottwald, T. R., Graham, J. H., Dixon, W. D., Schubert, T. S., Peacock, M. E., Dickstein, E. R., and Chaloux, P. H. 2000. Detection of a unique isolate of citrus canker bacterium from Key lime in Wellington and Lake Worth, Florida. (Abstr.) Proc. Int. Citrus Canker Res. Workshop, June 20-22, 2000. Florida Department of Agriculture and Consumer Services. Published on-line.

77. Takahishi, T., and Doke, N. 1984. A role of extracellular polysaccharides of Xanthomonas campestris pv. citri in bacterial adhesion to citrus leaf tissues in preinfectious stage. Ann. Phytopathol. Soc. Jpn. 50:565-573.

78. Timmer, L. W. 2000. Inoculum production and epiphytic survival of Xanthomonas cam- pestris pv. citri. (Abstr.) Proc. Int. Citrus Canker Res. Workshop, June 20-22, 2000. Florida Department of Agriculture and Consumer Services. Published on-line.

79. Timmer, L. W., Garnsey, S. M., and Graham J. H., eds. 2000. Compendium of Citrus Diseases, 2nd ed. American Phytopathological Society, St. Paul, MN.

80. Timmer, L. W., Gottwald, T. R., and Zitko, S. E. 1991. Bacterial exudation from lesions of Asiatic citrus canker and citrus bacterial spot. Plant Dis. 75:192-195.

81. Timmer, L. W., Zitko, S. E., and Gottwald, T. R. 1996. Population dynamics of Xanthomonas campestris pv. citri on symptomatic and asymptomatic citrus leaves under various environmental conditions. Proc. Int. Soc. Citriculture 1:448-451.

82. U.S. Dep. Agric., Animal Plant Health Inspection Serv., Plant Prot. Quarantine. 1999. Safeguarding American plant resources - A stakeholder review of the APHIS-PPQ safeguarding system. USDA-APHIS-PPQ. Summary Rep. Published on-line.

83. Vauterin, L., Rademaker, J., and Swings, J. 2000. Synopsis of the taxonomy of the genus Xanthomonas. Phytopathology 90:677-682.

84. Vernière, C., Hartung, J. S., Pruvost, O. P. Civerolo, E. L., Alvarez, A. M., Maestri, P. and Luisetti, J. 1998. Characterization of phenotypically distinct strains of Xanthomona axonopodis pv. citri from Southwest Asia. Eur. J. Plant Pathol. 104:477-487.

85. Whiteside, J. O. 1985. How serious a threat is canker to Florida citrus production? Citrus Ind. Mag. 66:6, 10, 12-14, 16-17.

86. Whiteside, J. O. 1986. Citrus canker: Some facts, speculations, and myths about this highly dramatized bacterial disease. Citrus Veg. Mag. 44:14, 55-56, 64

87. Whiteside, J. O. 1988. The history and rediscovery of citrus canker in Florida. Citrograph 73:197-206. 